\title{
Noninvasive Technologies for Primate Conservation in the 21st Century
}

\author{
A. K. Piel ${ }^{1}$ (D) A. Crunchant ${ }^{2}$ - I. E. Knot ${ }^{3} \cdot$ C. Chalmers $^{2}$ - P. Fergus ${ }^{2}$. \\ M. Mulero-Pázmány ${ }^{2} \cdot$ S. A. Wich ${ }^{2,3}$
}

Received: 18 September 2020 / Accepted: 22 July 2021 /Published online: 22 October 2021

(C) Crown 2021

\begin{abstract}
Observing and quantifying primate behavior in the wild is challenging. Human presence affects primate behavior and habituation of new, especially terrestrial, individuals is a time-intensive process that carries with it ethical and health concerns, especially during the recent pandemic when primates are at even greater risk than usual. As a result, wildlife researchers, including primatologists, have increasingly turned to new technologies to answer questions and provide important data related to primate conservation. Tools and methods should be chosen carefully to maximize and improve the data that will be used to answer the research questions. We review here the role of four indirect methods - camera traps, acoustic monitoring, drones, and portable field labsand improvements in machine learning that offer rapid, reliable means of combing through large datasets that these methods generate. We describe key applications and limitations of each tool in primate conservation, and where we anticipate primate conservation technology moving forward in the coming years.
\end{abstract}

Keywords Endangered $\cdot$ Methods $\cdot$ Monitoring $\cdot$ Remote Sensing $\cdot$ Tools

Handling Editor: Joanna M. Setchell.

A. K. Piel

a.piel@ucl.ac.uk

1 Department of Anthropology, University College London, London, UK

2 School of Biological and Environmental Sciences, Liverpool John Moores University, Liverpool, UK

3 Institute for Biodiversity and Ecosystem Dynamics, University of Amsterdam, Amsterdam, Netherlands 


\section{Introduction}

Observing and quantifying primate behavior in the wild is challenging (Williamson and Feistner 2003). Primates live across a vegetation gradient, from dense tropical and montane forests to savanna mosaics (Lehman and Fleagle 2006). Some are entirely arboreal and others nearly entirely terrestrial; when not habituated to humans, it is common for individuals to flee on contact (Williamson and Feistner 2003). As a result, visual study can be restricted to a few groups already under study or habituated for tourism.

Human presence affects primate behavior (Crofoot et al. 2010; Nowak et al. 2014) and habituation of new, especially terrestrial, groups is a time-intensive process that carries with it ethical and health concerns (Allan et al. 2020; Doran-Sheehy et al. 2007; Gazagne et al. 2020; Jack et al. 2008; Williamson and Feistner 2003), especially during the recent pandemic when primates are at even greater risk than usual (Gillespie and Leendertz 2020; Melin et al. 2020). As a result, wildlife researchers, including primatologists, have increasingly turned to new technologies as indirect methods to answer questions and provide important data related to primate conservation.

In this article we attempt to summarize some of the key advances driving data collection and analyses in primate conservation. This is by no means a comprehensive summary of the tools available to primate conservationists. Not only is that beyond the scope of this article, but there is a steady stream of new tools available to eager technologists (e.g., broad reviews on applicable technologies for wildlife conservation: Berger-Tal and Lahoz-Monfort 2018; Marvin et al. 2016; Pimm et al. 2015). Some of these tools are hardware, some are software, and some integrate them both, and in so doing are transformational. These and other systems generate new questions of inquiry, new methods of data collection, and with them, encourage the development of new analytical tools to investigate them.

These innovative tools take multiple forms and can be implemented at the data collection and analysis stage. In the review that follows, we discuss examples of both: camera traps (CT), passive acoustic monitoring (PAM), drones, and portable genomics labs as means of collecting indirect (and often, remotely sensed) data for primate conservation, and developments in machine learning for analyses of especially big data. At the data collection stage, remotely sensed data often complement direct behavioral observations by human observers in the field, or replace them entirely where ground-truthing has been previously established (Leyequien et al. 2007). The diversity of information that we can now extract from indirect evidence has transformed what we can understand about individuals, groups, and populations, all without ever directly observing an animal (Lynn et al. 2016). At the data analysis stage, in parallel with improvements in data collection, recent improvements in how we move data means that some of the limitations that have historically plagued research are steadily being overcome.

We begin by reviewing what we consider to be four increasingly common and informative technological developments and describe the ethical consideration necessary in their deployment, and then their application to monitoring primates and threats. We then highlight recent improvements in machine learning and (big) data analysis, before concluding with a discussion on the limitations of these methods, and where we see the future of technology in primate conservation. 


\section{Which Technologies?}

\section{Camera Traps}

Camera trapping is the use of motion-sensitive cameras to record videos or pictures of humans or animals (Kucera and Barrett 2011). The technique dates back nearly a century and has become almost ubiquitous in studies of wildlife research and conservation (Wearn and Glover-Kapfer 2019). CTs have long targeted large, charismatic mammals (Ahumada et al. 2011; Cove et al. 2013; Gerber et al. 2010; Kauffman et al. 2007), but have more recently expanded into assessing entire wildlife communities, including small and large species (Cusack et al. 2015a; Kays et al. 2009).

CTs share critical advantages with other remote sensing technologies. They collect data automatically, can be deployed in remote areas for extended periods (many months), record on a 24-h cycle, and are noninvasive and minimally disruptive to wildlife (Meek et al. 2014, 2016). The application of CT has seen remarkable growth and diversification to broad ecological questions and especially in its application to primate research and conservation, including documenting species presence or distribution ( Fang et al. 2020; Rovero and Zimmerman 2016).

\section{Passive Acoustic Monitoring}

Many primate species are characterized by long calls that travel a few hundred meters or even multiple kilometers (Delgado 2006; Mitani and Stuht 1998; Wich and Nunn 2002). These characteristics make call detection an effective way of identifying species presence.

Passive acoustic monitoring describes a system composed of microphones (hereafter acoustic sensors) and in-house storage capacity, which is often synchronized to detect and monitor wildlife sounds in both marine and terrestrial environments. PAM is applicable to any taxa that produces acoustic signals, including insects, fish, herpetofauna, birds, and mammals (Sugai et al. 2019). While the first system that listened to wildlife sounds was deployed underwater during World War 1 (reviewed in SousaLima et al. 2013), recent advances in bioacoustics have expanded the applications of acoustic sensors for terrestrial species (Blumstein et al. 2011; Sugai et al. 2019), including primates (Kalan et al. 2015; Piel 2018; Spillmann et al. 2015). PAM is noninvasive and especially applicable when visual detection is limited, for instance in dense tropical forests, at night, or when weather conditions are poor. It can be deployed for long periods in the field (months or years) and simultaneously at multiple locations and thus offers the possibility to monitor animal calls at large spatiotemporal scales. The increasing interdisciplinary collaboration between engineers and field ecologists is driving new, affordable, and effective PAM-related tools with reduced size and weight.

\section{Drones}

The use of drones in primatology started $c a$. $10 \mathrm{yr}$ ago to facilitate data collection on three main aspects that are relevant to primate conservation (Koh and Wich 2012): 1) land-cover classification and monitoring changes, 2) obtaining data on primate presence/absence and density, and 3) detecting 


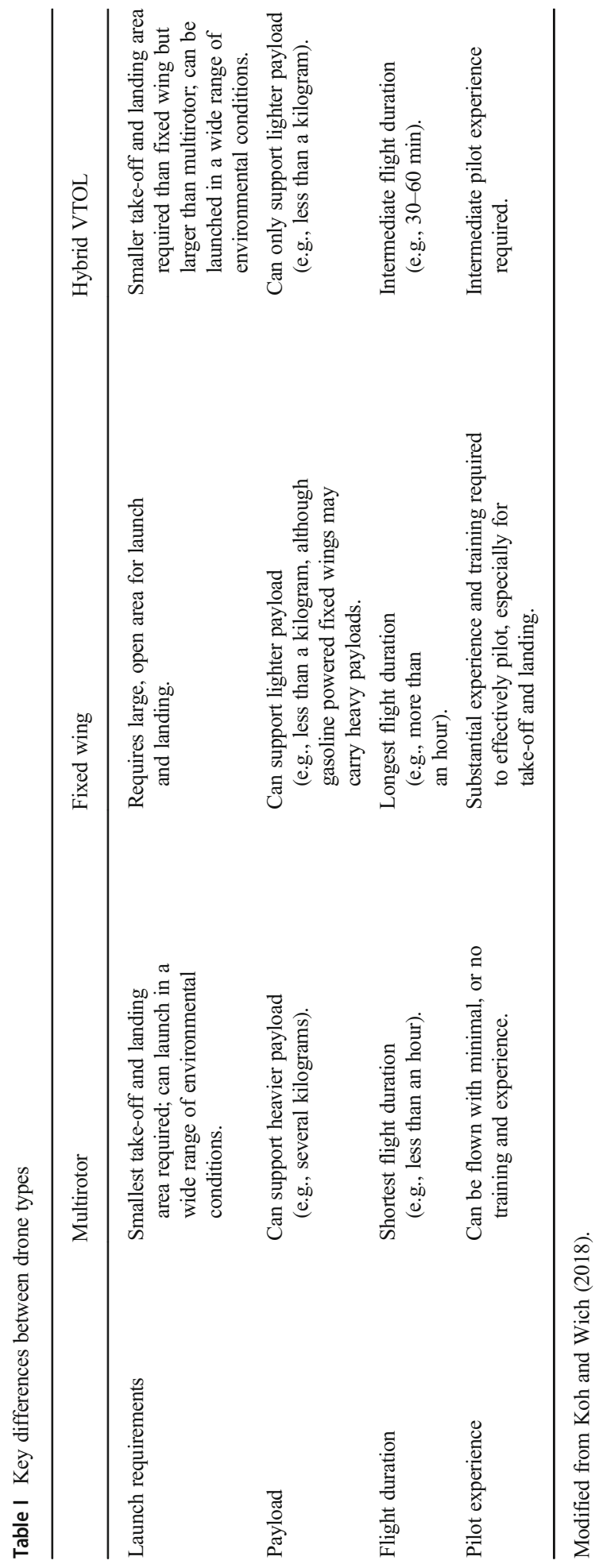


poachers. Other drone usages such as monitoring of food availability, remotely studying social behavior, or identifying individuals have not yet been conducted. Despite the decade since their introduction to the field, there have been relatively few published studies on the use of drones in primatology (Bonnin et al. 2018; Spaan et al. 2019; Zhang et al. 2020). For a more in-depth overview of the usage of drones in conservation we refer the reader to several review articles (Chabot and Bird 2015; Jiménez López and Mulero-Pázmány 2019; Nowak et al. 2019) and a recent book (Wich and Koh 2018). Here, we summarize the advantages and disadvantages of the three primary drone models (Table I).

\section{Portable Genomics Labs}

Primate feces have long been used in endocrinological, diet, and genetic studies. Endocrinologically, hormonal data reveal mechanisms that inform on primate behavior, health, causes and consequences of stress, and even life history (Beehner and Bergman 2017; Higham 2016). Feces also provide researchers with a catalog of consumed plant species and parts, enabling us to map important food sources and assess the role of primates as seed dispersers for forest regeneration (Kalbitzer et al. 2019). More recently, we can now apply metagenomics to primate feces to more comprehensively reveal primate diet, parasites, and population genetics (Srivathsan et al. 2016). The genetic material in primate feces allows us to identify individuals and use those data for censusing (Arandjelovic and Vigilant 2018; Vigilant and Guschanski 2009), to understand genetic structure, and to identify population boundaries (Eriksson et al. 2004). Feces have long revealed key data on the health of wild primates (Nunn and Gillespie 2016), especially in light of increasing anthropogenic activity (Chapman et al. 2005).

Genomics is an increasingly valuable tool in wildlife conservation (Frankham et al. 2010). It is important for species identification and the dynamics of endangered populations (McMahon et al. 2014) and contributes to identifying inbreeding depression, population structure, and the effect of population fragmentation (Hoban et al. 2013). Moreover, molecular epidemiology from genomic data is an increasingly common tool in primate health monitoring (Gilardi et al. 1999). Several studies have now shown the potential of combining noninvasive samples with portable genomics for, e.g., parasitology (Knot et al. 2020), sexing (Guevara et al. 2018), and species identification (Seah et al. 2020). Portable genomics has been demonstrated across habitats, from rainforests (Menegon et al. 2017; Pomerantz et al. 2018), to dry forests (Guevara et al. 2018), mountainous terrains (Parker et al. 2017), and even polar regions (Goordial et al. 2017; Johnson et al. 2017) and offers a way to address some of the critical limitations to traditional lab work that relies on field samples.

Despite the benefits of molecular research for primate conservation, traditional molecular labs are located far away from field sites and consist of bulky and expensive machines. This means researchers often invest many weeks and much funding toward storing, processing, and transporting samples for later analyses. At the same time this often creates dependency of local researchers on foreign collaborators, and numerous range countries are now encouraging if not requiring researchers to conduct analyses in 


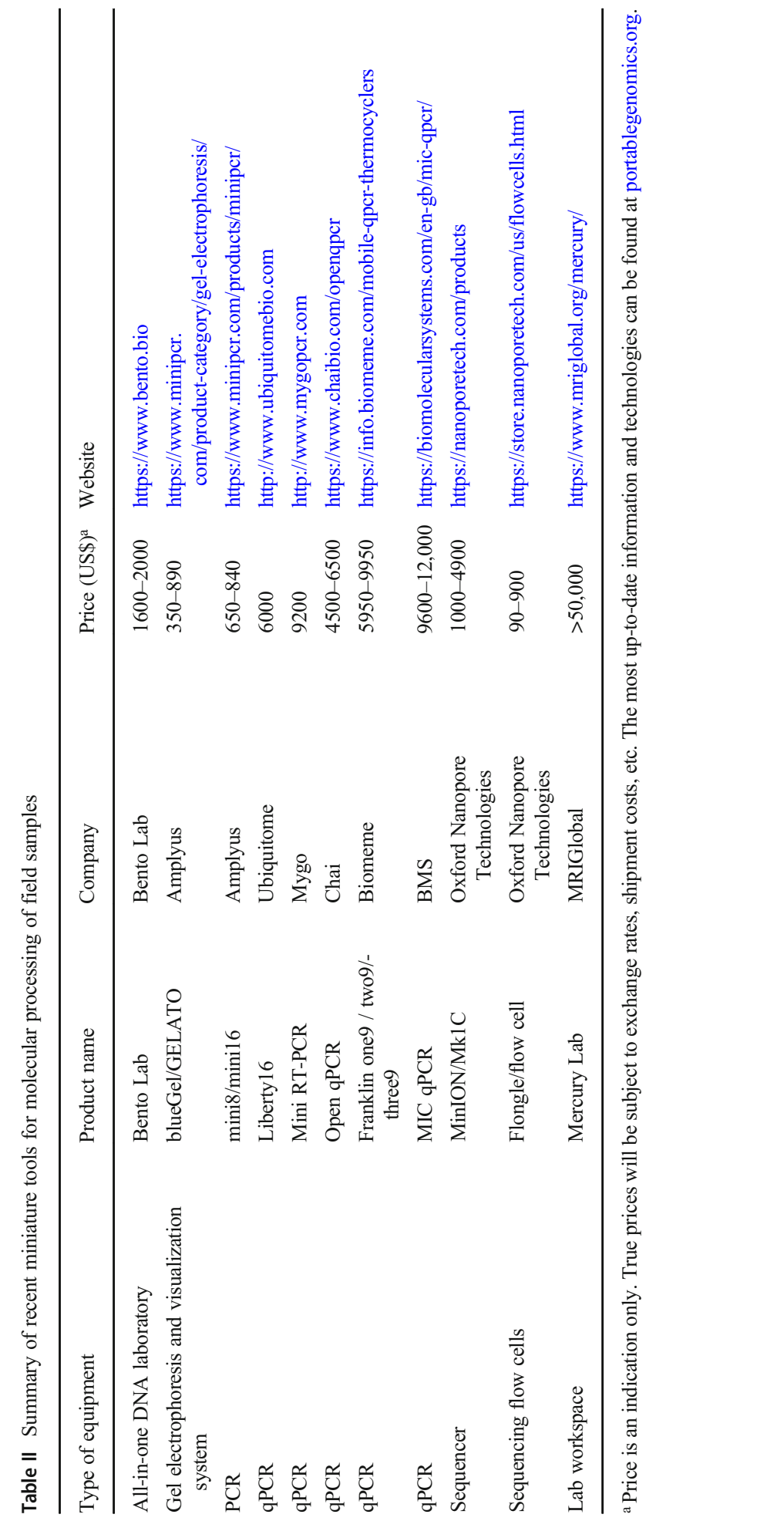


country. Thanks to a revolution in miniaturizing molecular equipment (Table II), this presents new opportunities for a decentralization of conservation research efforts. One example is from Oxford Nanopore Technologies, which launched the MinION in 2014, a portable and compact USB-powered sequencer (Jain et al. 2016). This miniaturization is now pervasive, from portable real-time polymerase chain reaction (qPCR) and gel electrophoresis systems to thermocyclers and even all-in-ones that offer extraction and sequencing preparation (Marx 2015). Incorporating fecal samples into field research protocols will be a valuable approach to obtain more information on a wide variety of primates, and these current technological advances present an exciting opportunity to analyze this information on site.

\section{Ethical Considerations of Remote Monitoring}

Before we discuss the application of these technologies to primate conservation specifically, we must first address the ethical and logistical considerations of access and exposure. As has been described elsewhere in detail (Sandbrook et al. 2018), new technologies are not a panacea for all primate conservation challenges. Although those described here offer clear benefits to data collection and analyses, their deployment must be thoroughly considered before use. The ability of remote sensing tools to incidentally (or deliberately, in the case of poachers) reveal the location, movement, and behavior of individuals raises concerns about informed consent, privacy, civil liberties, and fear of arrest. To our knowledge, there is no standard for determining when images or sounds captured from remote sensing can be shared or used (Pebsworth and LaFleur 2014), despite the growing need for universal agreements on these and related contexts that require formal guidance.

A recent discussion of the ethical issues related to camera trapping, for example, laid out recommendations for a basic code of conduct (Sharma et al. 2020). These include discussion of steps to obtain appropriate permission to use and deploy cameras to the consultations and meeting necessary to agree on terms that govern disclosure decisions. These issues are permeated by questions and differences in culture, value, power, and even law (Brittain et al. 2020). Historically, even well-intended conservation efforts have had negative consequences for some groups of people. For example, protecting wildlife can displace indigenous communities, even when local stakeholders are engaged in conservation policy (Adams and Hutton 2007). Aware of these negative repercussions, as practitioners our obligation is to identify the beneficiaries but also those who are likely to suffer from these decisions. In this sense, we echo recent calls for a more holistic approach to these complex issues of the ethics of conservation research, beyond what institutions require and inclusive of what local stakeholders deserve (Brittain et al. 2020).

It is also important to critically examine who controls how information flows and is processed, and how can these processes be democratized (Arts et al., 2015). For example, researchers in the Canadian territories of Manitoba and Nunavut are involving indigenous communities in the camera trapping process and tapping into their traditional ecological knowledge of the region (Clark et al. 2018). We support these 
improved attempts at inclusivity when planning and especially implementing the deployment of remote sensing technology for data collection.

\section{Avenues for Investigation}

\section{Detection, Presence-Absence, Prioritization}

An important first step in wildlife conservation is detecting a species presence and thereafter, identifying priority areas (Groves et al. 2002). In most cases, this involves weighing important metrics such as forest loss and forest loss rate, size of the area in need of protection, relative species (or overall phylogenetic) diversity, and measures of irreplaceability or vulnerability (Carvalho et al. 2020; Isaac et al. 2007; Ondei et al. 2019). Just as important is assessing a species presence, especially for cryptic, elusive, or rare species where distribution and ranging patterns are unknown. Although challenging, establishing species presence is an early and fundamental step in conservation, necessary for studying population trends.

One common analytical tool for doing this is to model occupancy (Cove et al. 2013; Crunchant et al. 2020). Occupancy is the proportion of an area used by a species (MacKenzie et al. 2017; MacKenzie and Royle 2005). Occupancy models use detection/nondetection data from multiple visits of a given area to infer the probability of species presence and provide a useful tool to assess the population status (i.e., declining, stable, or increasing). They also allow researchers to determine the predictors, such as vegetation, season, etc., that most influence animal presence (e.g., Crunchant et al. 2020). Although a common technique across wildlife studies, occupancy modeling is far less common in primatology. CTs, PAM, and drones can provide data on animal habitat use, especially important across vast areas that researchers cannot regularly monitor.

CT is widely used to reveal primate habitat use. For instance, in a case study from western Tanzania, occupancy models built from CT data revealed chimpanzee (Pan troglodytes) use of an extremely large home range to be highly variable across space and season (Crunchant et al. 2020). Seasonal changes in habitat use and in diet have been observed using CT in wild mandrills (Mandrillus sphinx: Hongo et al. 2018), blonde capuchin monkeys (Sapajus flavius: Medeiros et al. 2019) and wild Japanese macaques (Macaca fuscata: Hanya et al. 2018).

Besides documenting animal presence, CT footage has the advantage over other techniques (e.g., PAM) in revealing the sex and age of those that pass by cameras (e.g., Head et al. 2013). From a conservation perspective, monitoring life history landmarks, such as births, deaths, and immigrations/dispersal events reveal demographic patterns that inform and are informed by conservation strategies (Galvis et al. 2014; Strier 1991). While confirming a species presence is a critical first step toward conserving it, establishing group demography can offer insight into population health, especially given that some threats disproportionately affect individuals of certain age-sex classes (i.e., with younger indiviudals more succeptible; Lilly et al. 2002).

For decades researchers have deployed CTs terrestrially, tacitly acknowledging that cameras could not access higher-canopy-level dwelling species. The last few years, however, have seen the emergence of arboreally deployed cameras. Early studies 
targeted areas such as canopy crossing points, thought to be used by numerous taxa, including primates (Gregory et al. 2014), where high canopy-species inventories were conducted (Whitworth et al. 2016). In some cases, arboreal deployments have targeted particular primate species (e.g., Prolemur simus) and shown that, in some areas, arboreally deployed cameras have higher detection rates than subcanopy cameras (Olson et al. 2012). More recent studies have focused on extracting CT data for building occupancy models and revealing species richness (Chen et al. 2021; Johnson et al. 2020; Moore et al. 2020).

The use of PAM is well established in wildlife behavior and conservation (Balantic and Donovan 2019; Brauer et al. 2016; Campos-Cerqueira and Aide 2016; Comer et al. 2014), but it is seldom used to confirm primate presence and habitat use. Two reasons may explain this. First, the historic success of long-term projects that rely on direct observations of habituated groups may have favored a methodological inertia that suppressed innovation and creativity. Second, all the great apes (Fruth et al. 2018) and some strepsirrhines (Kappeler 1998) build nests for sleeping, which remain on the landscape for months, and from which researchers can derive habitat use, saving them the financial and logistical burden of deploying a new technology. Thus, although the application of PAM remains atypical in primate research, there is a growing niche for this method to reveal primate presence, abundance, and behavior.

Two of the earliest studies applied PAM to wild great apes. In one of these, researchers deployed 20 acoustic sensors in the Taï National Park, Côte d'Ivoire, to assess the potential of a customized algorithm for the automated detection of chimpanzee buttress drumming and the loud calls of Diana (Cercopithecus diana) and king colobus (Procolobus badius) monkeys over 35-45 km² (Kalan et al. 2015). The use of PAM and a semiautomated call detector provided similar results to data collection via walked transects. The authors argued that sensor deployment is far less time consuming than walking transects. That same year, the second study was published, where researchers deployed 20 sensors successfully detected wild male orangutans (Pongo pygmaeus) from $\leq 900 \mathrm{~m}$, including localizing callers to $<60 \mathrm{~m}$ (Spillmann et al. 2015). Detection algorithms correctly identified species from almost half a mile $(700 \mathrm{~m})$, demonstrating the geographic reach of such a system, especially when individual callers can be identified (Spillmann et al. 2017).

Two other studies compared the efficiency of CT and PAM in primate detection. In one, camera traps and acoustic sensors were deployed to study sika deer (Cervus nippon) and Japanese macaques (Macaca fuscata) in Japan (Enari et al. 2019) used. The authors showed that acoustic sensors were superior, largely due to the increased (spatial) detection coverage-100-7000 times larger-than CTs, as well as far more reliable when using automated detectors for auditory compared to visual signals. In comparing automated detectors for acoustic vs. camera trap footage of the monkeys, they noted that whereas images of animals rarely change, call parameters respond to the intrinsic (age-sex class) and extrinsic physical (rainfall, wind) and social (activity) context. Alas, although PAM offers more effective detection, automated detection may be more complicated, with many species exhibiting high intracaller acoustic variability (Bouchet et al. 2012; Zimmermann and Lerch 1993).

The second study compared the efficiency of PAM and CT in detecting chimpanzees in the Issa Valley, Tanzania (Crunchant et al. 2020). Detectability with both methods varied across seasons, likely due to social and ecological factors that influence 
chimpanzee party size and vocalization rate. Nonetheless, PAM was more efficient than $\mathrm{CT}$, confirming chimpanzee absence in fewer than 10 days of recordings, 5 times faster than CT data (Crunchant et al. 2020). Additional work comparing methods is necessary to more comprehensively understand the advantages of each method and which questions they can best address.

The use of drones to detect animals is a growing application across taxa and habitats. Although for some species the animal-background color contrast is sufficient to facilitate detection, for many species that is insufficient (Chabot et al. 2019; Linchant et al. 2015). As a result, conservation scientists sometimes use other evidence of wildlife to assess their presence and distribution, such as nests (chimpanzees: Bonnin et al. 2018; alligators: Elsey and Trosclair 2016). In one of the first demonstrations of this application, researchers used a camera on a fixed wing drone and flew line transects over chimpanzee habitat in Gabon (van Andel et al. 2015). The fraction of ground nests detected in the aerial images was far higher (49\%) in open, coastal forests than closed, inland forests (8\%), suggesting an important nest-forest color contrast in aiding detection. A follow-up study in a mosaic landscape in western Tanzania compared nest detections from ground surveys and aerial images (Bonnin et al. 2018). Only a fraction $(9.6 \%)$ of the ground nests were detected from the aerial images, but there was a significant, but weak relationship between the ground and aerial nest numbers. The fraction of nests observed in aerial images compared to the ground (39.9\%) was lower in this study than in Gabon, likely due to methodological differences (van Andel et al. 2015). In Tanzania, detection probability of nests was mainly influenced by image resolution (Bonnin et al. 2018).

In some cases, drones provide imagery from which animals themselves - and not nests - can be detected. A comparison of ground observations of spider monkeys (Ateles geoffroyi) in Mexico with detections by human analysts on thermal infrared images showed that there was good concordance between the ground and aerial counts for small parties, but the aerial counts were higher for larger parties, indicating that ground observers do not see as many individuals as aerial cameras do (Spaan et al. 2019). Owing to the difficulties of detecting primates directly in the tree canopy with visual spectrum cameras, scientists have resorted to thermal infrared cameras that can detect the heat radiated from primates (Burke et al. 2019; Kays et al. 2019; Spaan et al. 2019). These studies have used multirotor drones with a variety of thermal infrared cameras to detect several primate species and have the best detection probabilities at dawn and dusk when the vegetation is relatively cool. A study that focused on Bornean orangutans (Pongo pygmaeus morio) in Sabah established that orangutans, and the smaller proboscis monkeys (Nasalis larvatus), can be detected and distinguished from each other in the thermal signal on the basis of their size (Burke et al. 2019). As early demonstrations of the efficacy of drones and especially thermal imagery to detect wild primates, these studies have been enormously constructive. Limitations remain, however, in detections.

Specifically, although thermal cameras are effective in detecting species in the upper canopy, individuals even just under the top level of the canopy are generally not detected (Kays et al. 2019). In fact, in general, we know little about false negatives, which remains an issue during analyses. Figuring out ways to correct for that is important. Further, once daytime temperatures rise and the canopy warms, higher individuals will not be as detectable given the low temperature differential (Kays 
et al. 2019). Even though detection was high at night, distinguishing between species was difficult, which the authors argued could potentially be remedied by combining thermal imagery with flash photography or infrared illumination so that visual spectrum cameras can be used to facilitate species classification (Kays et al. 2019).

Lastly, innovations in portable labs have also enhanced our ability to remotely detect primates. Several studies have demonstrated the possibility of using portable sequencers for species identification in the field through DNA barcoding, which is limited to one gene region per sample (Blanco et al. 2020; Menegon et al. 2017; Pomerantz et al. 2018). Further, metabarcoding offers the potential to sequence mixed DNA barcode amplicons from bulk community or pooled samples (Krehenwinkel et al., 2019 b). Metabarcoding using Illumina sequencing has been applied to a variety of primatological research questions, for example to assess parasite diversity (Gogarten et al. 2020; Pafčo et al. 2018). Metabarcoding is also possible using MinION sequencing, but few studies have taken advantage of this (Krehenwinkel et al., 2019b). This is largely due to the fact that the individual reads have error rates between $5 \%$ and $15 \%$, meaning the more closely related the individuals, the more unreliable the readout. For spatially restricted species, this is likely less of a concern. There are signs of improvement in reducing these errors, however (Krehenwinkel et al. 2019a), with recent reported sequencing accuracy up to $97 \%$ (Baldi and La Porta 2020) and the R10.3 chemistry having a $>99.87 \%$ accuracy compared to Illumina sequencing (Chang et al. 2020). Furthermore, bioinformatics pipelines still focus mostly on Illumina or PacBio data. Development of new pipelines designed to handle MinION data is expected to improve the applicability of metabarcoding for species identification from community or pooled samples and thus offer another way to indirectly confirm species presence.

\section{Abundance and Density}

Once species presence is confirmed, a natural next parameter to establish is abundance (or density), especially important in species monitoring, evaluating extinction risk, and assessing the efficacy of conservation policy and practice. Estimations of population size have long on extractions from observations made on line transects (Buckland et al. 2010; Kolowski and Alonso 2012; Teelen 2007) or from feces (Goossens et al. 2006; Guschanski et al. 2009; Lynn et al. 2016), nest counts (Kouakou et al. 2009; Morgan et al. 2006), and vocalizations (Kidney et al. 2016).

Different statistical approaches can be used to estimate animal density from camera footage, whether animals are individually recognizable or not. When individuals are individually recognizable through a combination of facial and bodily characteristics (e.g., ear colors and forms, presence of scars), spatial capture-recapture (SCR) models can be applied (e.g., Borchers and Efford 2008; Efford 2004), for example to estimate chimpanzee density (Després-Einspenner et al. 2017; Head et al. 2013). The accuracy of SCR with CTs has been empirically evaluated based on known individual chimpanzees at Taï Forest, Ivory Coast (Després-Einspenner et al. 2017). Results indicated that nearly all weaned individuals were detected on only 5 cameras deployed for 38 weeks and camera trap derived densities were highly accurate and precise. SCR models can also be used when individuals are unmarked/unidentified but this requires intensive sampling and generates low-precision estimates (Chandler and Andrew Royle 2013). 
When animals are not recognizable via identifiable markings, as can occur for example in, nocturnal species, the random encounter model (REM) can estimate density using average animal group size and day range, and the distance and angle within which it detects animals. It requires camera sensitivity and animal speed movement to be measured (Rowcliffe et al. 2008, 2011, 2016). The REM model was later expanded (and relabeled as REST: random encounter and staying time) to assess densities even when individuals were not recognizable (Nakashima et al. 2018). The accuracy of the REM model remains to be demonstrated with more tests needed under field conditions (e.g., Cusack et al. 2015a; Rovero et al. 2013).

Another approach when individuals are not recognizable is camera trap distance sampling (CTDS). This applies distance sampling methods (e.g., Buckland et al. 2015) with extended point-transect methods (Howe et al. 2017). CTDS has been evaluated with chimpanzees in Tai Forest, Ivory Coast. The results showed that the CT-derived density estimate was accurate $\left(0.66 \mathrm{ind} . / \mathrm{km}^{2}\right.$ vs. a true density of $\left.0.67 \mathrm{ind} . / \mathrm{km}^{2}\right)$ and less biased than that calculated from line transects with nest counts $\left(0.78-0.84 \mathrm{ind} / \mathrm{km}^{2}\right.$ vs. a true density of 0.89 ind. $/ \mathrm{km}^{2}$; Kouakou et al. 2009), further demonstrating the efficacy of CTs in assessing primate density. CTDS is not dependent on previous knowledge of known individuals and thus can be applied in areas where little other information is available, as shown recently in a broad-based wildlife survey in Salonga National Park, DRC (Bessone et al. 2020).

Like CTs, acoustic sensors can also both detect animal presence and reveal animal density. This was initially demonstrated for marine species (e.g., Minke whales [Balaenoptera acutorostrata]: Martin et al., 2012); reviewed in Marques et al. 2013; McDonald and Fox 1999) before being expanded to terrestrial species (e.g., Cape peninsula moss frog [Arthroleptella lightfooti]: Borchers et al. 2015; Measey et al. 2017; Stevenson et al. 2015; ovenbirds [Seiurus aurocapilla]: Dawson and Efford 2009; Efford et al. 2009). Like with CT data, the main approaches to estimate abundance have been adapted from observational encounters and include capturerecapture (CR), distance sampling (DS), and acoustic spatial capture-recapture (aSCR), reviewed in more detail in Marques et al. (2013). No study has yet used PAM to estimate primate density. However, spatially explicit CR methods with humans acting as acoustic detectors was used to estimate yellow-cheeked gibbon (Nomascus annamensis) density in northeastern Cambodia, using bearing estimates to detected groups to improve density estimates, and results were promising (Kidney et al. 2016). aSCR methods require a priori knowledge of call rate (the number of calls produced per unit of time), to convert the density of calls (the number of calls per unit time per unit space) derived statistically from the acoustic survey into caller density (the number of animals per unit space). Call rate data can be obtained by following animals and recording call events.

Like with PAM, drone data show good promise in providing data on primate density, but few empirical studies have been conducted to date. Although drones have been used to obtain data on the distribution of a wide variety of taxa (Barasona et al. 2014; Chabot and Bird 2015; Mulero-Pázmány et al. 2015; Wich and Koh 2018), few studies have applied this technique to primates. This could be due to the fact that primates often occur in vegetation types that pose challenges for data collection (Ancrenaz et al. 2005). Studies with manned aircrafts have indicated that orangutan nests can be detected by observers on a small, low-flying helicopter and converted into 
orangutan density (Ancrenaz et al. 2005). A natural extension of this was to evaluate whether an off-the-shelf visual spectrum camera fitted to a drone could be used to detect nests and compare these observations to ground surveys. Results of two studies, one on orangutans (Wich et al. 2015) and another on chimpanzees (Bonnin et al. 2018), showed that a low, but consistent, proportion of nests that were observed from the ground are detectable from the air. A third study using a drone with a thermal infrared camera to determine the presence and count the number of spider monkeys in Mexico showed similarly encouraging results, with high reliability between aerial and ground counts of individual monkeys (Spaan et al. 2019). These studies indicate that aerial counts from camera-fitted drones offer an exciting new tool to monitor population trends in wild primate populations.

Because great ape nest numbers have to be converted into great ape densities through a conversion that involves other variables such as nest decay and nest building rate, the confidence intervals from survey data are usually large, which make them less suitable for detecting small population changes (Kouakou et al. 2009; Piel et al. 2015). From the aforementioned studies it thus seems that counting primates from the air also requires correction factors in most cases to yield accurate estimates. It remains to be determined whether such correction factors can be established and how they differ between vegetation types for the same species and between species living in the same vegetation types. It is likely that aerial counts using thermal infrared will work best for primate species that sleep in relatively open canopies of emergent, relatively large trees. For those species, correction factors may not even be necessary. For species that are smaller and/or sleep below the canopy or in tree holes the usage of thermal infrared will be less suitable and correction factors far more important (and larger).

\section{Main Threats}

\section{Poaching}

The technologies that we review here can detect more than animals themselves; these tools are potentially capable of revealing threats to primates and their habitat as effective as the primate themselves. All over the world wild primates are extracted from their natural habitat for either consumption, use in traditional medicine, the exotic pet trade, or used as trophy and status symbols, causing major threats to their distribution and abundance worldwide (Ni et al. 2018; Nijman et al. 2017). Poaching occurs predominantly for food and for some species also during human-primate conflict situations, and is one of the major causes leading to species declines (Meijaard et al. 2010, 2011; Wich and Marshall 2016).

Poaching is widespread and occurs across protected areas, plantations, logging concessions, and forest reserves. As a result there is considerable interest in reducing poaching pressure on primate species and evaluating whether technology can facilitate such a reduction (Mulero-Pázmány et al. 2014; Wich and Koh 2018). When poaching occurs in large landscapes that are covered in dense vegetation, poacher detection is challenging. This means that technological solutions need to cover large swaths of an area rapidly and with high poacher-detection probability. Due to poachers often operating outside of daylight hours, one direction that conservation managers 
and researchers have turned to is the employment of thermal infrared cameras to detect poachers. Further, predictive modelling can be used in areas where poaching has the highest likelihood of occurring to automate such missions (Olivares-Mendez et al. 2015).

Although the application of drones to detecting poachers is promising, areas for improvement remain. First, habitat type will impact the proportion of detected (and thus missed) poachers. One study found that drones using thermal infrared cameras in relatively open miombo woodland failed to detect $\sim 60 \%$ of human subjects even during optimal flight times that maximized the thermal contrast of subjects to the surrounding vegetation (Hambrecht et al. 2019; see also Mulero-Pázmány et al. 2014). Canopy cover, distance from the flight path, and flight altitude all negatively influenced detection probability. Because thermal infrared signals do not carry through thick layers of vegetation it is unlikely that poachers in dense forest will be detected with this method, although potentially this offers opportunities for indirect detection from camp fires (Burke et al. 2018). Machine learning is important to remove variability that arises from human analysts and is poised to dramatically improve detection success rates (Bondi et al. 2019; Longmore et al. 2017). Second, predictive modelling for optimizing drone flights would benefit from more studies and easy-to-use software applications for users. Third, long-flight drones are essential due to the large areas that need to be covered. This could be achieved through fixed-winged drones with power systems such as gas engines, batteries in combination with photovoltaic cells on wings (for areas and/ or seasons with high solar radiation), or hydrogen. Such systems will likely be larger than the relatively small fixed-wing systems that are predominantly used in conservation and hence will likely need to land on wheels instead of the belly and need some sort of runway. An alternative to cover large areas is to have several take-off and landing areas throughout an area and use swarms of smaller drones to cover larger areas.

Acoustic information can also be used to inform wildlife crime units of the presence of poachers. When combined, PAM and acoustic localization systems (ALSs) can reveal key threats to wild primates when used to identify the source of e.g. gunshots, axe, or chainsaw sounds. For example, CARACAL, a low-cost hardware and software platform, can identify gunshot origins from over $1 \mathrm{~km}$ with an accuracy of less than 35 m (Wijers et al. 2019). AudioMoth, another low-cost platform, can detect gunshots from up to $500 \mathrm{~m}$ (Hill et al. 2018).

Finally, genetic wildlife forensics aids bushmeat identification and illegally trafficked animals (McDowall 2008). Species identification benefits from molecular techniques, especially in cases where animal parts cannot be morphologically identified. For example, DNA barcoding can be used in forensic species identification (Comstock et al. 2003), whereas microsatellite data reveal the origins of seized illegal wildlife products and aid efforts to enhance law enforcement (Mondol et al. 2015). The latter technique is well-established when elephant or rhinoceros parts are confiscated by authorities (Wasser et al. 2004), but has not been used yet with primates, despite a growing demand (Oklander et al. 2020).

Traditionally, genetic wildlife forensics took place in a central lab. However, using portable genomics labs to investigate wildlife trade and crime from the field decentralizes otherwise bureaucratic processes, improves turnaround times for analyses, and reduces costs. In a recent study that used a qPCR to detect the illegal trade of the critically endangered European eel (Anguilla anguilla) at Hong Kong International 
Airport (Cardeñosa et al. 2019). The process of extracting and sequencing DNA was rapid ( $\sim 2 \mathrm{hr}$ ), mobile, and cost-effective (<US\$1.00 per sample). Additionally, DNA amplification using PCR and subsequent detection by electrophoresis have been performed on site for microsatellite genotyping of two primate species (Propithecus verreauxi and $P$. coquereli) in Madagascar (Guevara et al. 2018) (Guevara et al. 2018), and a fully portable field lab including the MinION facilitated the molecular species assignment of a Malagasy lemur species within a week, from animal capture to tissue collection, to phylogenetic analysis (Blanco et al. 2020). Finally, a recent study using threegene PCR and high resolution melting analysis showed encouraging accuracy for East African wildlife species identification (Ouso et al. 2020). This method is rapid, low-cost, and reliable, using melting profiles of ribosomal RNA gene PCR products, as opposed to mass barcode sequencing, as has been traditionally used for bushmeat (forensic) surveillance (Kimwele et al. 2012). These and other diverse applications of portable laboratories highlight the potential of field-based genomics to address data gaps in traded primate species and to improve data access for species conservation and management.

Landscape Integrity and Human-Wildlife Conflict Because habitat loss, fragmentation, and degradation are negatively influencing primate populations, it is important to determine the vegetation classes in which primates occur and monitor habitat change (Estrada et al. 2017). One of the most effective and efficient ways of doing that is with drones, and especially those using multispectral cameras. Although the number of sensors (and thus bands) in multispectral cameras can differ, these are often green, red, red-edge, and near-infrared (NIR) (Assmann et al. 2019). These sensors are often used for vegetation monitoring given that they allow for the calculation of band ratios such as the normalized difference vegetation index (NDVI), which is useful for landcover classification and plant health (Pettorelli 2013). Although these sensors are common tools in various remote sensing studies, for example to monitor protected areas (Coulter and Stow 2009) and rapidly assess ecological integrity (Díaz-Delgado et al. 2018), multispectral cameras have not yet been used in primate studies. Their potential use is diverse, however, capable of providing information on phenological patterns and for tree species detection, for instance. Traditionally, satellite images have been used for this process and these are still the method of choice for large-scale analyses (Voigt et al. 2018). However, new sensors offer comparable data for phenology (Brede et al. 2018). At a smaller scale, drones can offer advantages over satellite images, such as flexible data collection, capturing imagery below cloud cover and providing much higher resolution imagery than commercially available satellites (Rodríguez et al. 2012; Wich and Koh 2018). Such data allow the detection of very low impact logging activities, for instance, that would not be picked up by satellite images (Koh and Wich 2012).

Broadly, very few studies have used drones to map primate habitats. One study mapped Sumatran orangutan habitat with a fixed-wing drone that was equipped with a standard RGB camera to examine whether various vegetation classes in a reforested area could be distinguished from each other on drone images (Wich et al. 2018). This study indicated that some classes such as oil palm plantations were classified with a high accuracy, as were some of the reforestation classes, but that others such as logged forest had low accuracy and were classified as reforested. The use of multispectral data should improve such classifications. Another use of drone data can be as training data 
for classification algorithms for satellite image classifications (Szantoi et al. 2017). Owing to the very high resolution of drone images, they can potentially be used as an alternative to ground truthing, depending on location size, area accessibility, and the classes in need of classification. In two areas where Sumatran orangutan presence was mapped with a fixed-wing drone, researchers obtained very high resolution orthomosaics of the area in which seven land-cover classes could be distinguished (Szantoi et al. 2017). Drone-truthing data from these flights were subsequently used to train a supervised classification model on Landsat 8 images from the same data collection period. The accuracy of the classification was assessed with highresolution satellite data and indicated that accuracy was high for mature oil palm $(89 \%)$, logged (76\%), and reforested areas (76\%), but that riverine forest had a much lower accuracy (23\%) (Szantoi et al. 2017). These results indicate that the use of drones to acquire training data for algorithms that use satellite images to scale to larger surface areas is promising.

Drone images can also be used to obtain more detailed data on primate habitats. An early study examined the potential to determine tree species in chimpanzee habitat in Gabon on visual spectrum images taken from a camera on board a fixed wing drone (van Andel et al. 2015). Results indicated that 14 important chimpanzee food tree species could be identified in the images. This is a small number of species in a very diverse habitat, but the results reflect the potential of such an approach. The use of multispectral (and hyperspectral — which has hundreds of bands) cameras will allow the identification of much larger numbers of species and thus relatively large-scale tree species inventories of primate habitats and facilitate studies of primate behavioral ecology. In addition, such methods could be applicable in assessing whether areas are suitable for primate reintroduction.

An additional application of drones is assessing plant phenology (D'Odorico et al. 2020; Klosterman and Richardson 2017). In primatology, phenology monitoring is often conducted in a number of plots or along transects that are distributed throughout study sites (Marshall and Wich 2013), which gives a very useful but still limited dataset that does not cover a whole site and, in cases of primate species with large home ranges, might not be distributed throughout their whole range. If visual spectrum, multispectral, or hyperspectral drone images can be leveraged to provide such data through the calculation of various indices (e.g., enhanced vegetation index [EVI], normalized difference vegetation index [NDVI], and the entitled green-red normalized difference (GRND)] associated with leaf phenology (see Klosterman and Richardson 2017 for a nonprimate example), this would expand the spatial coverage of phenological patterns and allow studies to associate primate ranging (Peres 1994) and feeding behavior over large scales and in high detail. Studies in which drone-derived phenology indices are compared to phenology data from ground plots are needed to test this in areas where primates occur and should ideally address flower and fruit phenology as well as leaf phenology. Such studies have not been conducted yet. In a further step, actual leaf, flower, and fruit availability might be assessed from visual, multispectral, or hyperspectral data. This is as yet unexplored in primatology but methods are being developed and tested for fruits in the agricultural sector (Apolo-Apolo et al. 2020; Sarron et al. 2018; Senthilnath et al. 2016). 
CTs are also useful in areas that researchers have trouble accessing, such as agricultural areas and human settlements. Human-wildlife conflict pervades these areas, and cameras can reveal primates' use of them. In Guinea, for example, CT footage showed that chimpanzees temporally offset their use of key resources by visiting certain food trees when people are absent (Garriga et al. 2019). Similarly a study in Kibale National Park, Uganda, showed that chimpanzees crop-foraged during the night (Krief et al. 2014). Chimpanzees are not the only great ape that competes for land with humans. Orangutans range across forest of varying protected status, from national parks to commercial forest plantations, and abundance estimates require an understanding of their abundance over this mosaic landscape. A deployment of CTs across orangutan distribution revealed that individuals use two different types of commercial forest (Acacia and Eucalyptus), and secondary forest patches; the proximity to natural forest was the best predictor of their abundance (Spehar and Rayadin 2017). A similar study sought to assess Moor macaque (Macaca maura) use of farmland in Sulawesi, Indonesia. CTs provided data on the crop that monkeys foraged on most and the times of year monkeys were most active in people's fields (Zak and Riley 2017). Although these data were informative, the authors acknowledged that for they would need observational for monkey identity, group size, and amount of crop eaten. In this case, however, camera data contributed toward resolving human-wildlife conflict, providing data on what crops primates ate and when crop foraging occurred for farmers and conservationists alike.

\section{Disease}

Along with habitat loss, disease (and especially zoonoses) is a key threat to wild primates and to great apes specifically (Gilardi et al. 1999). Of the technologies described so far, portable genomics offers the most promising means of transforming how field workers study and respond to outbreaks. In situ genomics decreases turnaround times, due to the lack of logistical barriers to transport samples to a different location. Short turnaround times make the diagnostics especially important for research on disease outbreaks, as demonstrated by successful use of the MinION sequencer in human healthcare for real-time detection of Ebola virus in West Africa (Quick et al. 2016), Zika virus in Brazil (Quick et al. 2017), and the current global SARS-CoV-2 pandemic (Fauver et al. 2020). In the current SARS-CoV-2 pandemic, viral whole genome sequences of (human) patient samples have been produced at unprecedented rates, in such a way that they are actively informing government response to the outbreak (Oude Munnink et al. 2020). During such global crises, reliably diagnosing infected patients, or especially molecularly characterizing viral or bacterial strains, can have dramatic effects on mediation at the local and also international level.

These in situ tools may be most applicable to African great apes owing to their higher terrestriality and sociality, but also because of their close genetic relationship with humans, compared to orangutans which means that cross-species infection is a threat to both great apes and humans alike. Emerging infectious diseases are thus considered to be one of the three main threats for great apes, alongside poaching and deforestation (Nunn and Gillespie 2016). Respiratory diseases are responsible for outbreaks in chimpanzees (Negrey et al. 2019; Patrono et al. 2020) and gorillas (Grützmacher et al. 2016) and can cause significant mortality 
(Emery Thompson et al. 2018). Some of these outbreaks originate from human transmissions, confirmed through molecular analyses, and more of these early tests are being conducted on site. For example, at Dzanga Sangha Protected Areas in the Central African Republic, DNA amplification using PCR and subsequent detection by electrophoresis were performed on site to screen for human respiratory syncytial virus in western lowland gorillas (Gorilla gorilla gorilla). Tests revealed identical sequences of the virus in humans and gorillas (Grützmacher et al. 2016). Besides offering diagnoses, field labs that have qPCR facilities can provide quantitative information about viral loads in infected individuals. Evidence of rapid improvements to these field-facilities continues, with recently validated portable qPCR tests for canine distemper virus (Tomaszewicz Brown et al. 2020); the platform can be readily adapted to test for pathogens that pose high risks for primates.

These tools are particularly pertinent given the SARS-CoV-2 outbreak and its potential to inflict wild primates (Gillespie and Leendertz 2020). Several early studies suggest that African and Asian monkeys and apes, as well as some lemurs, are all likely to be highly susceptible to SARS-CoV-2. In comparison, platyrrhines and some strepsirrhines and tarsiers are less at risk of infection (Damas et al. 2020; Liu et al. 2020; Melin et al. 2020). Macaques (Macaca mulatta and M. fascicularis) have already been shown to be susceptible to this virus, whereas early results show no susceptibility for the virus in the common marmoset (Callithrix jacchus) (Lu et al. 2020).

Simultaneous molecular and observational in situ health monitoring of nonhuman primate species over the next few years offers the potential to reveal to what extent SARS-CoV-2 has infiltrated wild primates and simultaneously shine light on other infections currently going unnoticed.

\section{Data Processing}

One advantage of some of the techniques described in the preceding text is that they generate a large amount of data in a relatively short amount of time. Although data are typically beneficial to the conservation effort, the timely analysis of such data is a challenge (Norouzzadeh et al. 2018). For example, wildlife poaching is a global issue that impacts many primate species (Estrada et al. 2018) and although technologies produce useful raw data at short notice and real time, the significant delays in data processing limit its usefulness for poaching prevention and mitigation (O’Donoghue and Rutz 2016).

Until recently, data processing was often a manual process requiring hundreds of human-hours to deduce meaningful information that would inform conservation strategy. Areas such as computer vision and deep learning (DL) are helping to transform traditional data analysis processes undertaken by conservationists (Chen et al. 2019; Rowcliffe et al. 2016). Machine learning and advanced analytics that are already used in other domains such health and industry have seen limited use in conservation but have significant power in processing data and deriving new insights. By using these approaches data obtained from conservation studies can be directly used to identify trends and useful insights regarding animal and environmental health and behavior (Joseph et al. 2017). Machine learning can be used to automatically identify patterns and information of interest while discarding useless data (Kwok 2019).

Analytical platforms can automatically analyze data and provide useful visualizations to provide a clear understanding of primate populations across wide geographical 
boundaries. For example, object detection allows us to automatically detect and report specific individuals in large image and video catalogs and even live streams (Brust et al. 2017; Buehler et al. 2019), and count populations over to model biodiversity and population health. This significantly decreases (manual) analysis time therefore potentially reducing costs and streamlining conservation studies. In its application to PAM data, where manual data processing is extremely labour intensive and time consuming, automated signal processing; for example, deep learning for efficient data extraction is increasingly required (Bianco et al. 2019). These techniques have proven highly efficacious, for example for chimpanzee drumming, Diana and king colobus monkey loud calls (Heinicke et al. 2015; Kalan et al. 2015), male orangutan loud calls (Spillmann et al. 2015), and female gibbon calls (Clink et al. 2019), with potential to expand these analytical techniques to other taxa.

Traditional analytic approaches in conservation are reactive in nature, with data collected over long durations and analyzed retroactively. In many instances intervention strategies to address threats such as poaching require data long before they have traditionally been available. For example, when researchers rely on feedback from global positioning system (GPS) tracking devices that have been attached to animals, signal loss often suggests the death of the animal, often by poaching, which can trigger a response by a nearby team to confirm the death (Massawe et al. 2017). This is a reactive approach that does not prevent the poaching event (Tan et al. 2016). Preventive efforts are in place to detect poachers, for example using drones (Bondi et al. 2018a,b). However, these approaches either require in-field human participation or off-line processing of video footage, and both contribute to output delays.

This is an area where it makes sense to use computer vision and DL to automate the process. Although drones (more recently equipped with DL capabilities) have shown great utility in surveying geographical locations, this power can be extended through the distribution of global system for mobile communications (GSM)-enabled camera traps. GSM cameras can detect the onset of incidents such as poaching and react as the event occurs to allow an early intervention (Chalmers et al. 2019; Wang et al. 2019). Distributing technology in this way has proven useful in illegal logging where networks of sensors connecting trees allow rangers to detect when a break in communications is detected because trees are cut down (Mporas et al. 2020). These systems are still reactive; however, the latency between incident and detection is reduced dramatically compared to traditional methods. Visualizing the network on an analytics platform it is possible to see black holes appear where trees are being removed. This allows rangers to detect and intervene when trees are being cut down, potentially resulting in a significant reduction in illegal logging.

Similar applications concern the identification of rare or cryptic species of high conservation value from automating species or even individual detection. DL and other facial recognition algorithms have been used to automatically or semiautomatically identify species or individuals in ring-tailed lemurs (Lemur catta: Crouse et al. 2017), chimpanzees (Crunchant et al. 2017; Loos and Ernst 2013; Schofield et al. 2019), and gorillas (Brust et al. 2017), with clear implications for many other species (Norouzzadeh et al. 2018). 


\section{Limitations}

\section{Costs}

We hope to have made a compelling argument for the diverse applications of conservation technology to protect primate biodiversity. Cameras, acoustic sensors, drones, and portable labs have all been demonstrated to be reliable means of providing important data for practitioners and analysts alike. Technology comes at varying types and amounts of cost, though, which we summarize here.

Drones used by conservation researchers range in price from less than USD 1000 to more than USD 1 million, depending on factors such as sensors, flight duration, and durability. Increasingly, reliable drones can be purchased for hundreds (rather than thousands) of dollars, and thus have become more affordable to primatologists than even just a few years ago. The sensors that are attached to drones and that determine data type and quality drive the cost up. For example, one reason that hyperspectral cameras have not yet been used in primatology is their price tag, $c a$. USD 50,000 for a Rikola camera at the time of writing. This is easily the annual budget for many fieldbased projects and several times the annual budget for other field projects. Another limitation to drone use is that in most countries drone operations need to follow government guidelines, which almost always hamper operations in large areas because drones are restricted to being operated close (e.g., with $500 \mathrm{~m}$ ) to the remote pilot on the ground. Whilst such guidelines are important for safety, exemptions for drone usage beyond $500 \mathrm{~m}$ from the remote pilot would facilitate primate research.

For PAM, the cost of commercial devices and accessories (microphones, batteries) has likely prevented primatologists from using this monitoring technology to date. The good news is that, although initial systems were expensive, the costs of acoustic sensors have declined as technology has improved (e.g., Solo: ca. USD 100; Whytock and Christie 2017) or Audiomoth: ca. USD 75; Hill et al. 2018) and now align more closely with primatologists' research budgets.

The infrastructure necessary to run any portable genetics machinery (e.g., power) and support for running costs are necessary concerns for any future field genomicist. Both the cost per sample and the necessary equipment are obstacles for any initial project. A maximum per sample cost of USD 25 (which would satisfy $53 \%$ of potential users) and a maximum instrumentation cost of USD 6000 per unit (which would work for $60 \%$ of users) was recently estimated (Masters et al. 2019). Portable genomics instrumentation is approaching these desired price ranges.

\section{Power}

Camera traps and acoustic sensors typically run on AA batteries, often the type readily available in any nearby town. Power for drones and genomics labs is far more complicated and expensive. Flying drones to assess habitat or density of wide ranging, low-density primates such as orangutans requires long flights over large areas (e.g., >5 $\mathrm{km}^{2}$ ), as the camera footprint is small, meaning flight duration must be several hours to capture sufficient ground (Burke et al. 2019). This means that multiple batteries need to be available to avoid charging during the day. Most drone batteries cost below USD 
250, but some drone systems use multiple batteries (e.g., six for the DJI Matrice 600) simultaneously, which increases costs.

As any field biologist knows, the basic layout of a field lab can vary greatly. Some are basic tent or wooden structures without access to reliable electricity (Gowers et al. 2019; Menegon et al. 2017), whereas others are proper buildings with semi-reliable access to electricity (through access to the main electrical grid, a generator or solar panels) (Pomerantz et al. 2018; Quick et al. 2016). However, even the most luxurious field labs regularly have to deal with short or longer disruptions in the power supply. This complicates the scheduling of experiments that require a reliable energy supply for a fixed time, such as a $24-\mathrm{h}$ run on a sequencing machine. Solar panels can offer solutions in some sun-rich areas, and power stations can provide temporary energy solutions, allowing for 1 or 2 days of genetic analyses depending on the type of research being done. The energy requirements will have to be assessed per research project and location, but complete off-grid analyses are possible (Blanco et al. 2020; Gowers et al. 2019; Guevara et al. 2018).

\section{Sample Capacity and Networking}

For field genomics, a current limitation is that it is not high-throughput. Because of limited budgets, some researchers pursue the lowest possible costs per sample, sequencing, for example 3500 samples on one MinION flow cell (Srivathsan et al. 2019). However, collecting, preserving, and preparing this quantity of samples requires considerable time, which will be challenging to achieve with the limited capacity offered by current portable molecular labs such as Bento Lab and miniPCR. Currently, there is a trade-off between highthroughput/cost-effectiveness and near real-time analyses/flexibility of sample processing (Chang et al. 2020; Knot et al. 2020).

Another limitation of the MinION is the error rate, which some argue limits the utility for metabarcoding (Loit et al. 2019), although there is a growing expectation that this is soon to improve, with rapid developments in flow cell chemistry and bioinformatics pipelines (Baldi and La Porta 2020; Chang et al. 2020; Krehenwinkel 2019b). Currently field implementation of metabarcoding requires more testing and validation. Offline bioinformatics is also a limitation, as most remote field sites lack sufficient network capability. Even offline bioinformatic pipelines, including relevant databases, need to be prepared before undertaking any field genomics.

\section{Conclusion and Future Perspectives}

The technologies presented in this review are already essential tools for wildlife biologists, providing data on species diversity, abundance, habitat, threats, and animal movement. They are not yet common in the typical primatologist's toolbox, but there are signs of their proliferation. None of these should be seen as a silver-bullet for primate surveys, but rather as tool for use under specific circumstances, sometimes with particular species. For example, acoustic sensors work best with loud calling species and drones with those that can be spotted from above. 
For all technologies, access is limited to those with sufficient resources. For institutions and researchers with poor access to facilities or funds, large, upfront costs are prohibitive. Although successful deployment of some of these tools (e.g., drones, MinIONs) is necessarily restricted to those with training and expertise, others offer more potential for in-house research and development. In some cases, the support and training can be acquired remotely. For example, WILDLABS.NET supports an interdisciplinary community where researchers using field labs share ideas, challenges, and needs, and where collaborations are fostered, maintained, and expanded. Additional examples include hardware modifications to suit local needs, for example, tweaking the focal length and sensor sensitivity for the species of interest in camera traps (Welbourne et al. 2019), or else taking advantage of low-cost hardware such as the audiomoth (<USD50; Hill et al. 2018). In these ways, technologies can be developed in-house, independent of resource availability, so that their cost is not an impediment to their use, and their deployments can be sustained for conservation-related data gathering.

Nearly all of these techniques share scope for interdisciplinary collaboration. Those partnerships can be between scientists (e.g., biologists and engineers), and between academia and industry, where field primatologists can greatly benefit from the research and development of technologies that rely on large budgets to propel them forward. Together these groups can develop custom systems (and detectors) for particular habitats and species, and improve automated data mining, processing, and analysis. For example, Microsoft's AI for Earth platform provides a suite of tools under development, including for species classification and camera trap image processing (Joppa 2017).

Current technologies described here will also benefit in the near future from advances in microelectronics and the expansion of wireless communication networks (mobile networks or internet) that facilitate data transmission in real time, which is particularly important for responding to conservation threats at short notice (e.g., poaching) and to save unnecessary visits to collect them in person (e.g., SD cards for camera traps or acoustic sensors).

Combining technologies can further improve species monitoring. Drones have already been equipped with microphones that capture bat and bird sounds (August and Moore, 2019; Wilson et al., 2017), and there are plans to diversify drone-acoustic applications to monitor terrestrial species, such as gibbons (Borchers, pers. com.). Similarly, by integrating camera traps with acoustic sensors, we can capture complementary data on biotic interactions and animal behavior across multiple scales and provide a more thorough picture of animal presence, movement, and communication than by using any single method on its own (Buxton et al. 2018). Further integrating physiology and remote sensing adds an even higher resolution of data on animal behavior and conservation (Kays et al. 2015). A further step in this approach is the Internet of Things (IoT), where heterogeneous sensors (e.g., camera traps, environmental sensors, biologgers) can communicate with each other without human intervention, opening avenues for gathering data on animal behavior and environmental changes at matching spatiotemporal scales.

Costs are declining for most of these tools, and access is improving; there is rich scope in the application of these new technologies to help conserve and protect primate biodiversity. 


\section{Ethical Note}

This manuscript is a review of current technologies; there are no empirical data. This review adheres to the American Society of Primatologists principles for the ethical treatment of primates. The authors declare no conflicts of interest.

Data Availability This manuscript is a review of current technologies; there are no empirical data.

Acknowledgments We are grateful to the editors of the special issue, Alejandro Estrada and Paul Garber, for the invitation to submit this work and to two anonymous reviewers for feedback on an earlier version of this article.

Open Access This article is licensed under a Creative Commons Attribution 4.0 International License, which permits use, sharing, adaptation, distribution and reproduction in any medium or format, as long as you give appropriate credit to the original author(s) and the source, provide a link to the Creative Commons licence, and indicate if changes were made. The images or other third party material in this article are included in the article's Creative Commons licence, unless indicated otherwise in a credit line to the material. If material is not included in the article's Creative Commons licence and your intended use is not permitted by statutory regulation or exceeds the permitted use, you will need to obtain permission directly from the copyright holder. To view a copy of this licence, visit http://creativecommons.org/licenses/by/4.0/.

\section{References}

Adams, W. M., \& Hutton, J. (2007). People, parks and poverty: Political ecology and biodiversity conservation. Conservation and Society, 5(2), 147-183.

Ahumada, J. A., Silva, C. E. F., Gajapersad, K., Hallam, C., Hurtado, J., Martin, E., McWilliam, A., Mugerwa, B., O'Brien, T., Rovero, F., Sheil, D., Spironello, W. R., Winarni, N., \& ANdelman, S. J. (2011). Community structure and diversity of tropical forest mammals: Data from a global camera trap network. Philosophical Transactions of the Royal Society B: Biological Sciences, 366(1578), 2703-2711. https:// doi.org/10.1098/rstb.2011.0115.

Allan, A. T. L., Bailey, A. L., \& Hill, R. A. (2020). Habituation is not neutral or equal: Individual differences in tolerance suggest an overlooked personality trait. Science Advances, 1-16.

Ancrenaz, M., Gimenez, O., Ambu, L., Ancrenaz, K., Andau, P., Goossens, B., Payne, J., Sawang, A., Tuuga, A., \& Lackman-Ancrenaz, I. (2005). Aerial surveys give new estimates for orangutans in Sabah, Malaysia. Plos Biology, 3(1), 30-37.

Arts K, van der Wal R, Adams WM. (2015). Digital technology and the conservation of nature. Ambio 44: 661-673.https://link.springer.com/article/10.1007/s13280-015-0705-1

Apolo-Apolo, O. E., Martínez-Guanter, J., Egea, G., Raja, P., \& Pérez-Ruiz, M. (2020). Deep learning techniques for estimation of the yield and size of citrus fruits using a UAV. European Journal of Agronomy, 115(February), 126030. https://doi.org/10.1016/j.eja.2020.126030.

Arandjelovic, M., \& Vigilant, L. (2018). Non-invasive genetic censusing and monitoring of primate populations. American Journal of Primatology, 80(3), 1-14. https://doi.org/10.1002/ajp.22743.

Assmann, J. J., Kerby, J. T., Cunliffe, A. M., \& Myers-Smith, I. H. (2019). Vegetation monitoring using multispectral sensors - best practices and lessons learned from high latitudes. Journal of Unmanned Vehicle Systems, 7, 54-75. https://doi.org/10.1139/juvs-2018-0018.

August, T., \& Moore, T. (2019). Autonomous drones are a viable tool for acoustic bat surveys. BioRvix, 673772.

Balantic, C., \& Donovan, T. (2019). Dynamic wildlife occupancy models using automated acoustic monitoring data. Ecological Applications, 29(3). https://doi.org/10.1002/eap.1854.

Baldi, P., \& La Porta, N. (2020). Molecular Approaches for Low-Cost Point-of-Care Pathogen Detection in Agriculture and Forestry. Frontiers in Plant Science, 11(October), 1-16. https://doi.org/10.3389/fpls. 2020.570862 . 
Barasona, J. A., Mulero-Pázmány, M., Acevedo, P., Negro, J. J., Torres, M. J., Gortázar, C., \& Vicente, J. (2014). Unmanned aircraft systems for studying spatial abundance of ungulates: Relevance to spatial epidemiology. PLoS ONE, 9(12), 1-17. https://doi.org/10.1371/journal.pone.0115608.

Beehner, J. C., \& Bergman, T. J. (2017). The next step for stress research in primates: To identify relationships between glucocorticoid secretion and fitness. Hormones and Behavior, 91, 68-83. https://doi.org/10. 1016/j.yhbeh.2017.03.003.

Berger-Tal, O., \& Lahoz-Monfort, J. J. (2018). Conservation technology: The next generation. Conservation Letters, 11(6), 1-6. https://doi.org/10.1111/conl.12458.

Bessone, M., Kühl, H. S., Hohmann, G., Herbinger, I., N'Goran, K. P., Asanzi, P., Da Costa, P. B., Dérozier, V., Fotsing, E. D. B., Ikembelo Beka, B., Iyomi, M. D., Iyatshi, I. B., Kafando, P., Kambere, M. A., Moundzoho, D. B., Wanzalire, M. L. K., \& Fruth, B. (2020). Drawn out of the shadows: Surveying secretive forest species with camera trap distance sampling. Journal of Applied Ecology, 57(5), 963-974. https://doi.org/10.1111/1365-2664.13602.

Bianco, M. J., Gerstoft, P., Traer, J., Ozanich, E., Roch, M. A., Gannot, S., \& Deledalle, C.-A. (2019). Machine learning in acoustics: Theory and applications. The Journal of the Acoustical Society of America, 146(5), 3590-3628. https://doi.org/10.1121/1.5133944.

Blanco, M. B., Greene, L. K., Rasambainarivo, F., Toomey, E., Williams, R. C., Andrianandrasana, L., Larsen, P. A., \& Yoder, A. D. (2020). Next-generation technologies applied to age-old challenges in Madagascar. Conservation Genetics, 21(5), 785-793. https://doi.org/10.1007/s10592-020-01296-0.

Blumstein, D. T., Mennill, D. J., Clemins, P., Girod, L., Yao, K., Patricelli, G., Deppe, J. L., Krakauer, A. H., Clark, C., Cortopassi, K. A., Hanser, S. F., McCowan, B., Ali, A. M., \& Kirschel, A. N. G. (2011). Acoustic monitoring in terrestrial environments using microphone arrays: Applications, technological considerations and prospectus. Journal of Applied Ecology, 48(3), 758-767. https://doi.org/10.1111/j. 1365-2664.2011.01993.x.

Bondi, E., Fang, F., Hamilton, M., Kar, D., Dmello, D., Noronha, V., Choi, J., Hannaford, R., Iyer, A., Joppa, L., Tambe, M., \& Nevatia, R. (2019). Automatic detection of poachers and wildlife with UAVs. In F. Fang, M. Tambe, B. Dilikina, \& A. Plumptre (Eds.), Artificial intelligence and conservation (pp. 77-100). Cambridge University Press.

Bondi, E., Fang, F., Hamilton, M., Kar, D., Dmello, D., Choi, J., Hannaford, R., Iyer, A., Joppa, L., Tambe, L., \& Nevatia, R. (2018a). Spot poachers in action: Augmenting conservation drones with automatic detection in near real time. 32nd AAAI Conference on Artificial Intelligence. AAAI, 2018, 7741-7746.

Bondi, E., Kapoor, A., Dey, D., Piavis, J., Shah, S., Hannaford, R., Iyer, A., Joppa, L., \& Tombe, M. (2018b). Near real-time detection of poachers from drones in airsim. IJCAI International Joint Conference on Artificial Intelligence, 2018-July, 5814-5816.

Bonnin, N., Van Andel, A., Kerby, J., Piel, A., Pintea, L., \& Wich, S. (2018). Assessment of chimpanzee nest detectability in drone-acquired images. Drones, 2(2), 17. https://doi.org/10.3390/drones2020017.

Borchers, D., \& Efford, M. G. (2008). Spatially explicit maximum likelihood studies methods for capturerecapture studies. Biometrics, 64(2), 377-385. https://doi.org/10.1111/j.1541-0420.2007.00927.x

Borchers, D., Stevenson, B., Kidney, D., Thomas, L., \& Marques, T. (2015). A unifying model for capturerecapture and distance sampling surveys of wildlife populations. Journal of the American Statistical Association, 110(509), 195-204. https://doi.org/10.1080/01621459.2014.893884.

Bouchet, H., Blois-Heulin, C., Pellier, A. S., Zuberbuhler, K., \& Lemasson, A. (2012). Acoustic variability and individual distinctiveness in the vocal repertoire of red-capped mangabeys (Cercocebus torquatus). Journal of Comparative Psychology, 126(1), 45-56.

Brauer, C. L., Donivan, T. M., Mickey, R. M., Katz, J., \& Mitchell, B. R. (2016). A comparison of acoustic monitoring methods for common anurans of the northeastern United States. Wildlife Society Bulletin, 40(1), 140-149. https://doi.org/10.1002/wsb.619.

Brede, B., Gastellu-Etchegorry, J. P., Lauret, N., Baret, F., Clevers, J. G. P. W., Verbesselt, J., \& Herold, M. (2018). Monitoring forest phenology and leaf area index with the autonomous, low-cost transmittance sensor PASTiS-57. Remote Sensing, 10(7), 1-19. https://doi.org/10.3390/rs10071032.

Brittain, S., Ibbett, H., de Lange, E., Dorward, L., Hoyte, S., Marino, A., Milner-Gulland, E. J., Newth, J., Rakotonarivo, S., Veríssimo, D., \& Lewis, J. (2020). Ethical considerations when conservation research involves people. Conservation Biology, 34(4), 925-933. https://doi.org/10.1111/cobi.13464.

Brown, A. T., Mcaloose, D., Calle, P. P., Auer, A., Posautz, A., Slavinski, S., Brennan, R., \& walzer, C., \& Seimon, T. A. (2020). Development and validation of a portable, point-of-care canine distemper virus qPCR test. PLoS ONE, 1-22. https://doi.org/10.1371/journal.pone.0232044.

Brust, C. A., Burghardt, T., Groenenberg, M., Käding, C., Kühl, H. S., Manguette, M. L., \& Denzler, J. (2017). Towards automated visual monitoring of individual gorillas in the wild. In Proceedings: 2017 
IEEE International Conference on Computer Vision Workshops, ICCVW 2017, 2018-January (pp. 28202830). https://doi.org/10.1109/ICCVW.2017.333.

Buckland, S. T., Plumptre, A. J., Thomas, L., \& Rexstad, E. A. (2010). Line transect sampling of primates: Can animal-to-observer distance methods work? International Journal of Primatology, 31(3), 485-499. https://doi.org/10.1007/s10764-010-9408-4.

Buckland, S. T., Rexstad, E., Marques, T. A., \& Oedekoven, C. S. (2015). Distance sampling: methods and applications. Springer.

Buehler, P., Carroll, B., Bhatia, A., Gupta, V., \& Lee, D. E. (2019). An automated program to find animals and crop photographs for individual recognition. Ecological Informatics, 50(February), 191-196. https:// doi.org/10.1016/j.ecoinf.2019.02.003.

Burke, C., Longmore, S. N., Rashman, M., McAree, O., Piel, A., Wich, S. A., \& Hambrecht, L. (2018). Addressing environmental and atmospheric challenges for capturing high-precision thermal infrared data in the field of astro-ecology. In Proceedings of SPIE. (SPIE. Astronimcal Telescopes and Instrumentation, 10th-15th June (p. 63). Austin, TX. https://doi.org/10.1117/12.2311673

Burke, C., Rashman, M. F., Longmore, S. N., McAree, O., Glover-Kapfer, P., Ancrenaz, M., \& Wich, S. (2019). Successful observation of orangutans in the wild with thermal-equipped drones. Journal of Unmanned Vehicle Systems, 7(3), 235-257.

Buxton, R. T., Lendrum, P. E., Crooks, K. R., \& Wittemyer, G. (2018). Pairing camera traps and acoustic recorders to monitor the ecological impact of human disturbance. Global Ecology and Conservation, 16, e00493. https://doi.org/10.1016/j.gecco.2018.e00493.

Campos-Cerqueira, M., \& Aide, T. M. (2016). Improving distribution data of threatened species by combining acoustic monitoring and occupancy modeling. Methods in Ecology and Evolution. https://doi.org/10. 1111/2041-210X.12599.

Cardeñosa, D., Gollock, M. J., \& Chapman, D. D. (2019). Development and application of a novel real-time polymerase chain reaction assay to detect illegal trade of the European eel (Anguilla anguilla). Conservation Science and Practice, 1(5), e39. https://doi.org/10.1111/csp2.39.

Carvalho, F., Brown, K. A., Gordon, A. D., Yesuf, G. U., Raherilalao, M. J., Raselimanana, A. P., Soarimalala, V., \& Goodman, S. M. (2020). Methods for prioritizing protected areas using individual and aggregate rankings. Environmental Conservation, 47(2), 113-122. https://doi.org/10.1017/ S0376892920000090.

Chabot, D., \& Bird, D. M. (2015). Wildlife research and management methods in the 21st century: Where do unmanned aircraft fit in? Journal of Unmanned Vehicle Systems, 3(4), 137-155. https://doi.org/10.1139/ juvs-2015-0021.

Chabot, D., Stapleton, S., \& Francis, C. M. (2019). Measuring the spectral signature of polar bears from a drone to improve their detection from space. Biological Conservation, 237(July), 125-132. https://doi. org/10.1016/j.biocon.2019.06.022.

Chalmers, C., Fergus, P., Wich, S., \& Montanez, A. C. (2019). Conservation AI : Live stream analysis for the detection of endangered species using convolutional neural networks and drone technology. arXiv: 1910.07360. https://airshepherd.org/

Chandler, R. B., \& Andrew Royle, J. (2013). Spatially explicit models for inference about density in unmarked or partially marked populations. Annals of Applied Statistics, 7(2), 936-954. https://doi.org/10.1214/12AOAS610.

Chang, J. J. M., Ip, Y. C. A., Ng, C. S. L., \& Huang, D. (2020). Takeaways from mobile dna barcoding with bentolab and minion. Genes, 11(10), 1-18. https://doi.org/10.3390/genes11101121.

Chapman, C. A., Gillespie, T. R., \& Goldberg, T. L. (2005). Primates and the ecology of their infectious diseases: How will anthropogenic change affect host-parasite interactions? Evolutionary Anthropology, 14(4), 134-144. https://doi.org/10.1002/evan.20068.

Chen, D. M., Narváez-Torres, P. R., Tiafinjaka, O., Farris, Z. J., Rasoloharijaona, S., Louis, E. E., \& Johnson, S. E. (2021). Lemur paparazzi: Arboreal camera trapping and occupancy modeling as conservation tools for monitoring threatened lemur species. American Journal of Primatology, (April), 1-12. https://doi.org/ 10.1002/ajp. 23270

Chen, R., Little, R., Mihaylova, L., Delahay, R., \& Cox, R. (2019). Wildlife surveillance using deep learning methods. Ecology and Evolution, 9(17), 9453-9466. https://doi.org/10.1002/ece3.5410.

Clark, D.A., Brook, R., Oliphant-Reskanski, C., Laforge, M.P., Olson, K., Rivet, D. (2018). Novel range overlap of three ursids in the Canadian subarctic. Arctic Science, https://doi.org/10.1139/as-2018-0013.

Clink, D. J., Crofoot, M. C., \& Marshall, A. J. (2019). Application of a semi-automated vocal fingerprinting approach to monitor Bornean gibbon females in an experimentally fragmented landscape in Sabah, Malaysia. Bioacoustics, 28(3), 193-209. https://doi.org/10.1080/09524622.2018.1426042. 
Comer, C. E., Stuemke, L. A., Morrison, M. L., \& Maxey, R. W. (2014). Comparison of systematic roost searches and acoustic detection to determine occupancy of rare forest bats. Wildlife Society Bulletin, 38(1), 103-110. https://doi.org/10.1002/wsb.375.

Comstock, K. E., Ostrander, E. A., \& Wasser, S. K. (2003). Amplifying nuclear and mitochondrial DNA from African elephant ivory: A tool for monitoring the ivory trade. Conservation Biology, 17(6), 1840-1843. https://doi.org/10.1111/j.1523-1739.2003.00358.x.

Coulter, L. L., \& Stow, D. A. (2009). Monitoring habitat preserves in southern California using high spatial resolution multispectral imagery. Environmental Monitoring and Assessment, 152(1-4), 343-356. https:// doi.org/10.1007/s10661-008-0320-8.

Cove, M. V., Spínola, R. M., Jackson, V. L., Sáenz, J. C., \& Chassot, O. (2013). Integrating occupancy modeling and camera-trap data to estimate medium and large mammal detection and richness in a Central American biological corridor. Tropical Conservation Science, 6(6), 781-795. https://doi.org/10.1177/ 194008291300600606.

Crofoot, M. C., Lambert, T. D., Kays, R., \& Wikelski, M. C. (2010). Does watching a monkey change its behaviour? Quantifying observer effects in habituated wild primates using automated radiotelemetry. Animal Behaviour, 80(3), 475-480. https://doi.org/10.1016/j.anbehav.2010.06.006.

Crouse, D., Jacobs, R. L., Richardson, Z., Klum, S., Jain, A., Baden, A. L., \& Tecot, S. R. (2017). LemurFaceID: A face recognition system to facilitate individual identification of lemurs. $B M C$ Zoology, 2(1), 1-14. https://doi.org/10.1186/s40850-016-0011-9.

Crunchant, A. S., Borchers, D., Kühl, H., \& Piel, A. (2020). Listening and watching: Do camera traps or acoustic sensors more efficiently detect wild chimpanzees in an open habitat? Methods in Ecology and Evolution, 11(4), 542-552. https://doi.org/10.1111/2041-210X.13362.

Crunchant, A. S., Egerer, M., Loos, A., Burghardt, T., Zuberbühler, K., Corogenes, K., Leinert, V., Kulik, L., \& Kühl, H. S. (2017). Automated face detection for occurrence and occupancy estimation in chimpanzees. American Journal of Primatology, 79(3), 1-12. https://doi.org/10.1002/ajp.22627.

Cusack, J.J., Dickman, A. J., Rowcliffe, M. J., Carbone, C., MacDonald, D. W., \& Coulson, T. (2015a). Random versus game trail-based camera trap placement strategy for monitoring terrestrial mammal communities. PLoS ONE, e0126373, 1. https://doi.org/10.1371/journal.pone.0126373

Cusack, J. J., Swanson, A., Coulson, T., Packer, C., Carbone, C., Dickman, A. J., Kosmala, M., Lintott, C., \& Rowcliffe, J. M. (2015b). Applying a random encounter model to estimate lion density from camera traps in Serengeti National Park, Tanzania. Journal of Wildlife Management, 79(6), 1014-1021. https://doi.org/ 10.1002/jwmg.902.

Damas, J., Hughes, G. M., Keough, K. C., Painter, C. A., Persky, N. S., Corbo, M., Hiller, M., Koepfli, K.-P., Pfenning, A. R., Zhao, H., Genereux, D. P., Swofford, R., Pollard, K. S., Ryder, O. A., Nweeia, M. T., Lindblad-Toh, K., Teeling, E. C., Karlsson, E. K., \& Lewin, H. A. (2020). Broad host range of SARSCoV-2 predicted by comparative and structural analysis of ACE2 in vertebrates. bioRxiv, 2020.04.16.045302. https://doi.org/10.1101/2020.04.16.045302

Dawson, D. K., \& Efford, M. G. (2009). Bird population density estimated from acoustic signals. Journal of Applied Ecology, 46(6), 1201-1209. https://doi.org/10.1111/j.1365-2664.2009.01731.x.

Delgado, R. A. (2006). Sexual selection in the loud calls of male primates: Signal content and function. International Journal of Primatology, 27(1), 5-25. https://doi.org/10.1007/s10764-005-9001-4.

Després-Einspenner, M. L., Howe, E. J., Drapeau, P., \& Kühl, H. S. (2017). An empirical evaluation of camera trapping and spatially explicit capture-recapture models for estimating chimpanzee density. American Journal of Primatology, 79(7), 1-12. https://doi.org/10.1002/ajp.22647.

Díaz-Delgado, R., Cazacu, C., \& Adamescu, M. (2018). Rapid assessment of ecological integrity for LTER wetland sites by using UAV multispectral mapping. Drones, 3(1), 3. https://doi.org/10.3390/ drones3010003.

D’Odorico, P., Besik, A., Wong, C. Y. S., Isabel, N., \& Ensminger, I. (2020). High-throughput drone-based remote sensing reliably tracks phenology in thousands of conifer seedlings. New Phytologist, 226(6), 1667-1681. https://doi.org/10.1111/nph.16488.

Doran-Sheehy, D. M., Derby, A. M., Greer, D., \& Mongo, P. (2007). Habituation of western gorillas: The process and factors that influence it. American Journal of Primatology, 69, 1354-1369. https://doi.org/10. 1002/ajp.

Efford, M. (2004). Density estimation in live-trapping studies. Oikos, 106(3), 598-610. https://doi.org/10. 1111/j.0030-1299.2004.13043.x.

Efford, M. G., Dawson, D. K., \& Borchers, D. L. (2009). Population density estimated from locations of individuals on a passive detector array. Ecology, 90(10), 2676-2682.

Elsey, R. M., \& Trosclair, P. L. (2016). The use of an unmanned aerial vehicle to locate alligator nests. Southeastern Naturalist, 76-82. 
Emery Thompson, M., Machanda, Z. P., Scully, E. J., Enigk, D. K., Otali, E., Muller, M. N., Goldberg, T., Chapman, C. A., \& Wrangham, A. W. (2018). Risk factors for respiratory illness in a community of wild chimpanzees (Pan troglodytes schweinfurthii). Royal Society Open Science, 5.

Enari, H., Enari, H. S., Okuda, K., Maruyama, T., \& Okuda, K. N. (2019). An evaluation of the efficiency of passive acoustic monitoring in detecting deer and primates in comparison with camera traps. Ecological Indicators, 98(November 2018), 753-762. https://doi.org/10.1016/j.ecolind.2018.11.062.

Eriksson, J., Hohmann, G., Boesch, C., \& Vigilant, L. (2004). Rivers influence the population genetic structure of bonobos (Pan paniscus). Molecular Ecology, 13(11), 3425-3435. https://doi.org/10.1111/j. 1365-294X.2004.02332.x.

Estrada, A., Garber, P. A., Mittermeier, R. A., Wich, S., Gouveia, S., Dobrovolski, R., Nekaris, K. A. I., Nijman, V., Rylands, A. B., Maisels, F., Williamson, E. A., Bicca-Marques, J., Fuentes, J., Jerusalinsky, L., Johnson, S., Rodrigues de Melo, F., Oliveira, L., Schwitzer, C., Roos, C., et al (2018). Primates in peril: The significance of Brazil, Madagascar, Indonesia and the Democratic Republic of the Congo for global primate conservation. PeerJ, 2018(6), 1-57. https://doi.org/10.7717/peerj.4869.

Estrada, A., Garber, P. A., Rylands, A. B., Roos, C., Fernandez-Duque, E., Di Fiore, A., Nekaris, K. A.-I., Nijman, V., Heymann, E. W., Lambert, J. E., Rovero, F., Barelli, C., Setchell, J. M., Gillespie, T. R., Mittermeier, R. A., Arregoitia, L. V., de Guinea, M., Gouveia, S., Dobrovolski, R., et al (2017). Impending extinction crisis of the world's primates: Why primates matter. Science Advances, 3(1). https://doi.org/10.1126/sciadv.1600946.

Fang, Y. H., Li, Y. P., Ren, G. P., Huang, Z. P., Cui, L. W., Zhang, L. X., Garber, P. A., Pan, R.-L., \& Xiao, W. (2020). The effective use of camera traps to document the northernmost distribution of the western black crested gibbon in China. Primates, 61(2), 151-158. https://doi.org/10.1007/s10329-019-00774-5.

Fauver, J. R., Petrone, M. E., Hodcroft, E. B., Shioda, K., Ehrlich, H. Y., Watts, A. G., Vogels, C. B. F., Brito, A. F., Alpert, T., Muyombwe, A., Razeq, J., Downing, R., Cheemarla, N. R., Wyllie, A. L., Kalinich, C. C., Ott, I. M., Quick, J., Loman, N. J., Neugebauer, K. M., et al (2020). Coast-to-coast spread of SARSCoV-2 during the early epidemic in the United States. Cell, 181(5), 990-996. https://doi.org/10.1016/j. cell.2020.04.021.

Frankham, R., Ballou, J. D., \& Briscoe, D. A. (2010). Introduction to conservation genetics. Cambridge University Press.

Fruth, B., Tagg, N., \& Stewart, F. (2018). Sleep and nesting behavior in primates: A review. American Journal of Physical Anthropology, 166(3), 499-509. https://doi.org/10.1002/ajpa.23373.

Galvis, N., Link, A., \& Di Fiore, A. (2014). A novel use of camera traps to study demography and life history in wild animals: A case study of spider monkeys (Ateles belzebuth). International Journal of Primatology, 35(5), 908-918. https://doi.org/10.1007/s10764-014-9791-3.

Garriga, R. M., Marco, I., Casas-Díaz, E., Acevedo, P., Amarasekaran, B., Cuadrado, L., \& Humle, T. (2019). Factors influencing wild chimpanzee (Pan troglodytes verus) relative abundance in an agriculture-swamp matrix outside protected areas. PLOS ONE, 14(5), 1-16. https://doi.org/10.1371/journal.pone.0215545.

Gazagne, E., Hambuckers, A., Savini, T., Poncin, P., \& Huynen, M. (2020). Toward a better understanding of habituation process to human observer: A statistical approach in Macaca leonina (Primates : Cercopithecidea). Raffles Bulletin of Zoology, 68(September), 735-749. https://doi.org/10.26107/RBZ2020-0085.

Gerber, B., Karpanty, S. M., Crawford, C., Kotschwar, M., \& Randrianantenaina, J. (2010). An assessment of carnivore relative abundance and density in the eastern rainforests of Madagascar using remotelytriggered camera traps. Oryx, 44(2), 219-222. https://doi.org/10.1017/S0030605309991037.

Gilardi, K. V, Gillespie, T. R., Leendertz, F. H., Macfie, E. J., Travis, D. A., Whittier, C. A., \& williamson, E. A. (1999). Best practice guidelines for health monitoring and disease control in great ape populations. www.iucn.org/what/work_by_topic

Gillespie, T. R., \& Leendertz, F. H. (2020). Covid-19: Protect great apes during human pandemics. Nature, 579, 497. https://doi.org/10.1038/d41586-020-00859-y.

Gogarten, J. F., Calvignac-Spencer, S., Nunn, C. L., Ulrich, M., Saiepour, N., Nielsen, H. V., Deschner, T., Fichtel, C., Kappeler, P. M., Knauf, S., Müller-Klein, N., Ostner, J., Robbins, M. M., Sangmaneedet, S., Schülke, O., Surbeck, M., Wittig, R. M., Sliwa, A., Strube, C., et al (2020). Metabarcoding of eukaryotic parasite communities describes diverse parasite assemblages spanning the primate phylogeny. Molecular Ecology Resources, 20(1), 204-215. https://doi.org/10.1111/1755-0998.13101.

Goordial, J., Altshuler, I., Hindson, K., Chan-Yam, K., Marcolefas, E., \& Whyte, L. G. (2017). In situ field sequencing and life detection in remote $\left(79^{\circ} 26^{\prime} \mathrm{N}\right)$ Canadian high arctic permafrost ice wedge microbial communities. Frontiers in Microbiology, 8(Dec), 1-14. https://doi.org/10.3389/fmicb.2017.02594. 
Goossens, B., Chikhi, L., Ancrenaz, M., Lackman-Ancrenaz, I., Andau, P., \& Bruford, M. W. (2006). Genetic signature of anthropogenic population collapse in orang-utans. PLoS Biology, 4(2), 285-291. https://doi. org/10.1371/journal.pbio.0040025.

Gowers, G., Vince, O. J. C., Klarenberg, I., Ellis, T., \& Edwards, A. (2019). Entirely off-grid and solarpowered DNA sequencing of microbial communities during an ice cap traverse expedition. Genes, 1-10.

Gregory, T., Carrasco Rueda, F., Deichmann, J., Kolowski, J., \& Alonso, A. (2014). Arboreal camera trapping: Taking a proven method to new heights. Methods in Ecology and Evolution, 5(5), 443-451. https://doi.org/10.1111/2041-210X.12177.

Groves, C. R., Jensen, D. B., Valutis, L. L., Redford, K. H., Shaffer, M. L., Scott, J. M., Baumgartner, J. V., Higgins, J. V., Beck, M. W., \& Anderson, M. G. (2002). Planning for biodiversity conservation: Putting conservation science into practice. BioScience, 52(6), 499-512. https://doi.org/10.1641/0006-3568(2002) 052[0499:PFBCPC]2.0.CO;2.

Grützmacher, K. S., Köndgen, S., Keil, V., Todd, A., Feistner, A., Herbinger, I., Petrzelkova, K., Fuh, T., Leendertz, S. A., Calvignac-Spencer, S., \& Leendertz, F. H. (2016). Codetection of respiratory syncytial virus in habituated wild western lowland gorillas and humans during a respiratory disease outbreak. EcoHealth, 13(3), 499-510. https://doi.org/10.1007/s10393-016-1144-6.

Guevara, E. E., Frankel, D. C., Ranaivonasy, J., Richard, A. F., Ratsirarson, J., Lawler, R. R., \& Bradley, B. J. (2018). A simple, economical protocol for DNA extraction and amplification where there is no lab. Conservation Genetics Resources, 10(1), 119-125. https://doi.org/10.1007/s12686-017-0758-5.

Guschanski, K., Vigilant, L., McNeilage, A., Gray, M., Kagoda, E., \& Robbins, M. M. (2009). Counting elusive animals: Comparing field and genetic census of the entire mountain gorilla population of Bwindi Impenetrable National Park, Uganda. Biological Conservation, 142(2), 290-300. https://doi.org/10.1016/ j.biocon.2008.10.024.

Hambrecht, L., Brown, R. P., Piel, A. K., \& Wich, S. A. (2019). Detecting 'poachers' with drones: Factors influencing the probability of detection with TIR and RGB imaging in miombo woodlands, Tanzania. Biological Conservation, 233(February), 109-117. https://doi.org/10.1016/j.biocon.2019.02.017.

Hanya, G., Otani, Y., Hongo, S., Honda, T., Okamura, H., \& Higo, Y. (2018). Activity of wild Japanese macaques in Yakushima revealed by camera trapping: Patterns with respect to season, daily period and rainfall. PLoS ONE, 13(1), 1-18. https://doi.org/10.1371/journal.pone.0190631.

Head, J. S., Boesch, C., Robbins, M. M., Rabanal, L. I., Makaga, L., \& Kühl, H. S. (2013). Effective sociodemographic population assessment of elusive species in ecology and conservation management. Ecology and Evolution, 3(9), 2903-2916. https://oi.org/10.1002/ece3.670.

Heinicke, S., Kalan, A. K., Wagner, O. J. J., Mundry, R., Lukashevich, H., \& Kühl, H. S. (2015). Assessing the performance of a semi-automated acoustic monitoring system for primates. Methods in Ecology and Evolution, 6(7), 753-763. https://doi.org/10.1111/2041-210X.12384.

Higham, J. P. (2016). Field endocrinology of nonhuman primates: Past, present, and future. Hormones and Behavior, 84, 145-155. https://doi.org/10.1016/j.yhbeh.2016.07.001.

Hill, A. P., Snaddon, J. L., Prince, P., Piña, E., Patrick, C. C., Rogers, A., \& Hill, A. P. (2018). AudioMoth : Evaluation of a smart open acoustic device for monitoring biodiversity and the environment. Methods in Ecology and Evolution. https://doi.org/10.1111/2041-210X.12955.

Hoban, S. M., Hauffe, H. C., Perez-Espona, S., Arntzen, J. W., Bertorelle, G., Bryia, J., \& Frith, K. (2013). Bringing genetic diversity to the forefront of conservation policy and management. Conservation Genetic Resources, 5, 593-598.

Hongo, S., Nakashima, Y., Akomo-Okoue, E. F., \& Mindonga-Nguelet, F. L. (2018). Seasonal change in diet and habitat use in wild mandrills (Mandrillus sphinx). International Journal of Primatology, 39(1), 2748. https://doi.org/10.1007/s10764-017-0007-5.

Howe, E. J., Buckland, S. T., Després-Einspenner, M.-L., \& Kühl, H. S. (2017). Distance sampling with camera traps. Methods in Ecology and Evolution, 8, 1558-1565. https://doi.org/10.1111/2041-210X. 12790.

Isaac, N. J. B., Turvey, S. T., Collen, B., Waterman, C., \& Baillie, J. E. M. (2007). Mammals on the EDGE: Conservation priorities based on threat and phylogeny. PLOS ONE, 2(3). https://doi.org/10.1371/journal. pone.0000296.

Jack, K. M., Lenz, B. B., Healan, E., Rudman, S., Schoof, V. A. M., \& Fedigan, L. (2008). The effects of observer presence on the behavior of Cebus capucinus in Costa Rica. American Journal of Primatology, 70(5), 490-494. https://doi.org/10.1002/ajp.20512.

Jain, M., Olsen, H. E., Paten, B., \& Akeson, M. (2016). The Oxford Nanopore MinION : Delivery of nanopore sequencing to the genomics community. Genome Biology, 1-11. https:/doi.org/10.1186/ s13059-016-1103-0. 
Jiménez López, J., \& Mulero-Pázmány, M. (2019). Drones for conservation in protected areas: Present and future. Drones, 3(1), 10. https://doi.org/10.3390/drones3010010.

Johnson, C. L., Hilser, H., Linkie, M., Rahasia, R., Rovero, F., Pusparini, W., Hunowu, I., Patandung, A., Andayani, A., Tasirin, J., Nistyantara, L. A., \& Bowkett, A. E. (2020). Using occupancy-based cameratrap surveys to assess the Critically Endangered primate Macaca nigra across its range in North Sulawesi, Indonesia. Oryx, 54(6), 784-793. https://doi.org/10.1017/S0030605319000851.

Johnson, S. S., Zaikova, E., Goerlitz, D. S., Bai, Y., \& Tighe, S. W. (2017). Real-time DNA sequencing in the antarctic dry valleys using the Oxford nanopore sequencer. Journal of Biomolecular Techniques, 28(1), 2-7. https://doi.org/10.7171/jbt.17-2801-009.

Joppa, L. N. (2017). The case for technology investments in the environment. Nature, 552(7685), 325-328. https://doi.org/10.1038/d41586-017-08675-7.

Joseph, J., Torney, C., Kings, M., Thornton, A., \& Madden, J. (2017). Applications of machine learning in animal behaviour studies. Animal Behaviour, 124, 203-220. https://doi.org/10.1016/j.anbehav.2016.12. 005.

Kalan, A. K., Wagner, O. J. J., Heinicke, S., Mundry, R., Boesch, C., \& Kuehl, H. S. (2015). Towards the automated detection of primates using passive acoustic monitoring. Ecological Indicators, 54, 217-226. https://doi.org/10.1016/j.ecolind.2015.02.023.

Kalbitzer, U., McInnis, V., \& Chapman, C. A. (2019). Primates create seedling growth hotspots through pattern of dung deposition. African Journal of Ecology, 57(2), 190-197. https://doi.org/10.1111/aje. 12589.

Kappeler, P. M. (1998). Nests, tree holes, and the evolution of primate life histories. American Journal of Primatology, 46(1), 7-33. https://doi.org/10.1002/(sici)1098-2345(1998)46:1<7::aid-ajp3>3.0.co;2-\%23.

Kauffman, M. J., Sanjayan, M., Lowenstein, J., Nelson, A., Jeo, R. M., \& Crooks, K. R. (2007). Remote camera-trap methods and analyses reveal impacts of rangeland management on Namibian carnivore communities. Oryx, 41(1), 70-78. https://doi.org/10.1017/S0030605306001414.

Kays, R., Crofoot, M. C., Jetz, W., \& Wikelski, M. (2015). Terrestrial animal tracking as an eye on life and planet. Science, 348(6240), aaa2478-aaa2478. https://doi.org/10.1126/science.aaa2478.

Kays, R., Kranstauber, B., Jansen, P., Carbone, C., Rowcliffe, M., Fountain, T., \& Tilak, S. (2009). Camera traps as sensor networks for monitoring animal communities. Proceedings: Conference on Local Computer Networks, LCN, (October), 811-818. https://doi.org/10.1109/LCN.2009.5355046

Kays, R., Sheppard, J., Mclean, K., Welch, C., Paunescu, C., Wang, V., Kravit, G., \& Crofoot, M. (2019). Hot monkey, cold reality: Surveying rainforest canopy mammals using drone-mounted thermal infrared sensors. International Journal of Remote Sensing, 40(2), 407-419.

Kidney, D., Rawson, B. M., Borchers, D. L., Stevenson, B. C., Marques, T. A., \& Thomas, L. (2016). An efficient acoustic density estimation method with human detectors applied to gibbons in Cambodia. PLoS ONE, 11(5), 1-16. https://doi.org/10.1371/journal.pone.0155066.

Kimwele, C. N., Karisa, B. K., Stokes, M., Junga, J. O., Hanotte, O., Skilton, R. A., \& McElroy, D. (2012). DNA species surveillance: Monitoring bushmeat poaching and trading in Kenya using partial cytochrome b gene. African Journal of Biotechnology, 11(78), 14276-14286. https://doi.org/10.5897/ajb11.2813.

Klosterman, S., \& Richardson, A. D. (2017). Observing spring and fall phenology in a deciduous forest with aerial drone imagery. Sensors (Switzerland), 17(12), 1-17. https://doi.org/10.3390/s17122852.

Knot, I. E., Zouganelis, G. D., Weedall, G. D., Wich, S. A., \& Rae, R. (2020). DNA barcoding of nematodes using the MinION. Frontiers in Ecology and Evolution, 8(April), 1-11. https://doi.org/10.3389/fevo. 2020.00100 .

Koh, L. P., \& Wich, S. A. (2012). Dawn of drone ecology: Low-cost autonomous aerial vehicles for conservation. Tropical Conservation Science, 5(2), 121-132.

Kolowski, J. M., \& Alonso, A. (2012). Primate abundance in an unhunted region of the northern Peruvian Amazon and the influence of seismic oil exploration. International Journal of Primatology, 33(4), 958971. https://doi.org/10.1007/s10764-012-9627-y.

Kouakou, C. Y., Boesch, C., \& Kuehl, H. (2009). Estimating chimpanzee population size with nest counts: Validating methods in Taï National Park. American Journal of Primatology, 71(6), 447-457. https://doi. org/10.1002/ajp.20673.

Krehenwinkel, H., Pomerantz, A., Henderson, J. B., Kennedy, S. R., Lim, J. Y., Swamy, V., Shoobridge, J. D., Graham, N., Patel, N. H., Gillespie, R. G., \& Prost, S. (2019a). Nanopore sequencing of long ribosomal DNA amplicons enables portable and simple biodiversity assessments with high phylogenetic resolution across broad taxonomic scale. GigaScience, 8(5), 1-16. https://doi.org/10.1093/gigascience/ giz006. 
Krehenwinkel, H., Pomerantz, A., \& Prost, S. (2019b). Genetic biomonitoring and biodiversity assessment using portable sequencing technologies: Current uses and future directions. Genes, 10(11). https://doi.org/ 10.3390/genes 10110858 .

Krief, S., Cibot, M., Bortolamiol, S., Seguya, A., Krief, J. M., \& Masi, S. (2014). Wild chimpanzees on the edge: Nocturnal activities in croplands. PLOS ONE, 9(10). https://doi.org/10.1371/journal.pone.0109925.

Kucera, T. E., \& Barrett, R. H. (2011). A history of camera trapping. In A. F. O’Connell, J. Nichols, \& K. U. Karanth (Eds.), Animal ecology: Methods and analyses (pp. 9-26). Springer.

Kwok, R. (2019). AI empowers conservation biology. Nature, 567, 133-134.

Lehman, S. M., \& Fleagle, J. G. (2006). Biogeography and primates: A review. In L. Barret (Ed.), Primate biogeography (pp. 1-58). Developments in Primatology: Progress and Prospects. Springer US. https:// doi.org/10.1007/0-387-31710-4_1.

Leyequien, E., Verrelst, J., Slot, M., Schaepman-Strub, G., Heitkönig, I. M. A., \& Skidmore, A. (2007). Capturing the fugitive: Applying remote sensing to terrestrial animal distribution and diversity. International Journal of Applied Earth Observation and Geoinformation, 9(1), 1-20. https://doi.org/10. 1016/j.jag.2006.08.002.

Lilly, A. A., Mehlman, P. T., \& Doran, D. (2002). Intestinal parasites in gorillas, chimpanzees, and humans at Mondika research site, Dzanga-Ndoki National Park, Central African Republic. International Journal of Primatology, 23(3), 555-573. https://doi.org/10.1023/A:1014969617036.

Linchant, J., Lisein, J., Semeki, J., Lejeune, P., \& Vermeulen, C. (2015). Are unmanned aircraft systems (UASs) the future of wildlife monitoring? A review of accomplishments and challenges. Mammal Review, 45(4), 239-252. https://doi.org/10.1111/mam.12046.

Liu, Y., Hu, G., Wang, Y., Zhao, X., Ji, F., Ren, W., Gong, M., Ju, X., Zhu, Y., Cai, X., Wu, J., Lan, X., Xie, Y., Wang, X., Yuan, Z., Zhang, R., \& Ding, Q. (2020). Functional and genetic analysis of viral receptor ACE2 orthologs reveals broad potential host range of SARS-CoV-2. bioRxiv, 2020.04.22.046565. https://doi.org/10.1101/2020.04.22.046565

Loit, K., Adamson, K., Bahram, M., Puusepp, R., Anslan, S., Kiiker, R., Drenkhan, R., \& Tedersoo, L. (2019). Relative performance of MinION (Oxford Nanopore Technologies) versus Sequel (Pacific Biosciences) thirdgeneration sequencing instruments in identification of agricultural and forest fungal pathogens. Applied and Environmental Microbiology, 85(21), 1-20. https://doi.org/10.1128/AEM.01368-19.

Longmore, S. N., Collins, R. P., Pfeifer, S., Fox, S. E., Mulero-Pazmany, M., Bezombes, F., Goodwin, A., De Juan Ovelar, M., Knapen, J. H., \& Wich, S. A. (2017). Adapting astronomical source detection software to help detect animals in thermal images obtained by unmanned aerial systems. International Journal of Remote Sensing, 38, 2623-2638.

Loos, A., \& Ernst, A. (2013). An automated chimpanzee identification system using face detection and recognition. Eurasip Journal on Image and Video Processing, 2013, 1-17. https://doi.org/10.1186/16875281-2013-49.

Lu, S., Zhao, Y., Yu, W., Yang, Y., Gao, J., \& Wang, J. (2020). Comparison of SARS-CoV-2 infections among 3 species of non-human primates. bioRxiv, 1-27.

Lynn, M. S., Sechi, P., Chikhi, L., \& Goosens, B. (2016). Primate conservation genetics at the dawn of conservation genomics. In S. A. Wich \& A. W. Marshall (Eds.), An introduction to primate conservation (pp. 19-53). Oxford University Press.

MacKenzie, D. I., Nichols, J. D., Royle, J. A., Pollock, K. H., Bailey, L., \& Hines, J. E. (2017). Occupancy estimation and modeling: inferring patterns and dynamics of species occurrence. Elsevier.

MacKenzie, D. I., \& Royle, J. A. (2005). Designing occupancy studies: General advice and allocating survey effort. Journal of Applied Ecology, 42(6), 1105-1114. https://doi.org/10.1111/j.1365-2664.2005.01098.x.

Marcus Rowcliffe, J., Carbone, C., Jansen, P. A., Kays, R., \& Kranstauber, B. (2011). Quantifying the sensitivity of camera traps: An adapted distance sampling approach. Methods in Ecology and Evolution, 2(5), 464-476. https://doi.org/10.1111/j.2041-210X.2011.00094.x.

Marques, T. A., Thomas, L., Martin, S. W., Mellinger, D. K., Ward, J. A., Moretti, D. J., Harris, D., \& Tyack, P. L. (2013). Estimating animal population density using passive acoustics. Biological Reviews, 88(2), 287-309. https://doi.org/10.1111/brv.12001.

Marques, T. A., Thomas, L., Ward, J., DiMarzio, N., \& Tyack, P. L. (2009). Estimating cetacean population density using fixed passive acoustic sensors: An example with Blainville's beaked whales. The Journal of the Acoustical Society of America, 125(4), 1982-1994. https://doi.org/10.1121/1.3089590.

Marshall, A. J., \& Wich, S. (2013). Characterization of primate environments through assessment of plant phenology. In E. J. Sterling, N. Bynum, \& M. E. Blair (Eds.), Primate ecology and conservation: A handbook of techniques (pp. 103-127). Oxford University Press. https://doi.org/10.1093/acprof:oso/ 9780199659449.003.0007. 
Martin et al. (2012). Estimating minke whale (Balaenoptera acutorostrata) boing sound density using passive acoustic sensors. https:/onlinelibrary.wiley.com/doi/abs/10.1111/j.1748-7692.2011.00561.x

Marvin, D. C., Koh, L. P., Lynam, A. J., Wich, S., Davies, A. B., Krishnamurthy, R., Stokes, E., Starkey, R., \& Asner, G. P. (2016). Integrating technologies for scalable ecology and conservation. Global Ecology and Conservation, 7, 262-275. https://doi.org/10.1016/j.gecco.2016.07.002.

Marx, V. (2015). PCR heads into the field. Nature Methods, 12(5), 393-397. https://doi.org/10.1038/nmeth. 3369.

Massawe, E. A., Kisangiri, M., Kaijage, S., \& Seshaiyer, P. (2017). An intelligent real-time wireless sensor network tracking system for monitoring rhinos and elephants in Tanzania national parks: A review. International Journal of Advanced Smart Sensor Network Systems, 7(4), 1-11. https://doi.org/10.5121/ ijassn.2017.7401.

Masters, A., Ogden, R., Wetton, J. H., \& Dawnay, N. (2019). Defining end user requirements for a field-based molecular detection system for wildlife forensic investigations. Forensic Science International, 301, 231239. https://doi.org/10.1016/j.forsciint.2019.05.041.

McDonald, M. A., \& Fox, C. G. (1999). Passive acoustic methods applied to fin whale population density estimation. The Journal of the Acoustical Society of America, 105(5), 2643-2651. https://doi.org/10.1121/ 1.426880 .

McDowall, I. L. (2008). DNA technology and its applications in herpetological research and forensic investigations involving reptiles and amphibians. Applied Herpetology, 5, 371-385.

McMahon, B. J., Teeling, E. C., \& Höglund, J. (2014). How and why should we implement genomics into conservation? Evolutionary Applications, 7(9), 999-1007. https://doi.org/10.1111/eva.12193.

Measey, G. J., Stevenson, B. C., Scott, T., Altwegg, R., \& Borchers, D. L. (2017). Counting chirps: Acoustic monitoring of cryptic frogs. Journal of Applied Ecology, 54(3), 894-902. https://doi.org/10.1111/13652664.12810.

Medeiros, K., Bastos, M., Jones, G., \& Bezerra, B. (2019). Behavior, diet, and habitat use by blonde capuchin monkeys (Sapajus flavius) in a coastal area prone to flooding: Direct observations and camera trapping. International Journal of Primatology, 40(4-5), 511-531. https://doi.org/10.1007/s10764-019-00103-z.

Meek, P, Ballard, G. A., Fleming, P. J. S., Schaefer, M., Williams, W., \& Falzon, G. (2014). Camera traps can be heard and seen by animals. PLoS ONE, 9(10). https://doi.org/10.1371/journal.pone.0110832

Meek, P., Ballard, G., Fleming, P., \& Falzon, G. (2016). Are we getting the full picture? Animal responses to camera traps and implications for predator studies. Ecology and Evolution, 6(10), 3216-3225. https://doi. org/10.1002/ece3.2111.

Meijaard, E., Buchori, D., Hadiprakarsa, Y., \& Utami-atmoko, S. S. (2011). Quantifying killing of orangutans and human-orangutan conflict in Kalimantan, Indonesia. PLoS ONE, 6(11), 1-10. https://doi.org/10.1371/ journal.pone.0027491

Meijaard, E., Welsh, A., Ancrenaz, M., Wich, S., Nijman, V., \& Marshall, A. J. (2010). Declining orangutan encounter rates from Wallace to the present suggest the species was once more abundant. PLoS ONE, 5(8). https://doi.org/10.1371/journal.pone.0012042.

Melin, A. D., Janiak, M. C., Marrone III, F., Aorora, P. S., \& Higham, J. P. (2020). Comparative ACE2 variation and primate COVID-19 risk. BioRvix. https://doi.org/10.1101/2020.04.09.034967.

Menegon, M., Cantaloni, C., Rodriguez-Prieto, A., Centomo, C., Abdelfattah, A., Rossato, M., Bernardi, M., Xumerle, L., Loader, S., \& Delledonne, M. (2017). On site DNA barcoding by nanopore sequencing. PLoS ONE, 12(10), 1-18. https://doi.org/10.1371/journal.pone.0184741.

Mitani, J. C., \& Stuht, J. (1998). The evolution of nonhuman primate loud calls: Acoustic adaptation for longdistance transmission. Primates, 39(2), 171-182. https://doi.org/10.1007/BF02557729.

Mondol, S., Sridhar, V., Yadav, P., Gubbi, S., \& Ramakrishnan, U. (2015). Tracing the geographic origin of traded leopard body parts in the indian subcontinent with DNA-based assignment tests. Conservation Biology, 29(2), 556-564. https://doi.org/10.1111/cobi.12393.

Moore, J. F., Pine, W. E., Mulindahabi, F., Niyigaba, P., Gatorano, G., Masozera, M. K., \& Beaudrot, L. (2020). Comparison of species richness and detection between line transects, ground camera traps, and arboreal camera traps. Animal Conservation, 23(5), 561-572. https://doi.org/10.1111/acv.12569.

Morgan, D., Sanz, C., Onononga, J. R., \& Strindberg, S. (2006). Ape abundance and habitat use in the Goualougo Triangle, Republic of Congo. International Journal of Primatology, 27(1), 147-179. https:// doi.org/10.1007/s10764-005-9013-0.

Mporas, I., Perikos, I., Kelefouras, V., \& Paraskevas, M. (2020). Illegal logging detection based on acoustic surveillance of forest. Applied Sciences (Switzerland), 10(20), 1-12. https://doi.org/10.3390/ app10207379. 
Mulero-Pázmány, M., Barasona, J. Á., Acevedo, P., Vicente, J., \& Negro, J. J. (2015). Unmanned aircraft systems complement biologging in spatial ecology studies. Ecology and Evolution, 5(21), 4808-4818. https://doi.org/10.1002/ece3.1744.

Mulero-Pázmány, M., Stolper, R., Van Essen, L. D., Negro, J. J., \& Sassen, T. (2014). Remotely piloted aircraft systems as a rhinoceros anti-poaching tool in Africa. PLOS ONE, 9(1), 1-10. https://doi.org/10. 1371/journal.pone.0083873.

Nakashima, Y., Fukasawa, K., \& Samejima, H. (2018). Estimating animal density without individual recognition using information derivable exclusively from camera traps. Journal of Applied Ecology, 55(2), 735-744. https://doi.org/10.1111/1365-2664.13059.

Negrey, J. D., Reddy, R. B., Scully, E. J., Phillips-Garcia, S., Owens, L. A., Langergraber, K. E., Mitani, J. C., Thompson, M. E., Wrangham, R. W., Muller, M. N., Otali, E., Machanda, Z., Hyeroba, D., Grindle, C. A., Pappas, T. E., Palmenberg, A. C., Gern, J. E., \& Goldberg, T. L. (2019). Simultaneous outbreaks of respiratory disease in wild chimpanzees caused by distinct viruses of human origin. Emerging Microbes and Infections, 8(1), 139-149. https://doi.org/10.1080/22221751.2018.1563456.

Ni, Q., Wang, Y., Weldon, A., Xie, M., Xu, H., Yao, Y., Zhang, M., Li, Y., Zeng, B., \& Nekaris, K. A. I. (2018). Conservation implications of primate trade in China over 18 years based on web news reports of confiscations. PeerJ, 6(e6069), 1-18. https://doi.org/10.7717/peerj.6069.

Nijman, V., Spaan, D., \& Rode-Margono, E. V. A. J. (2017). Changes in the primate trade in Indonesian wildlife markets over a 25-year period: Fewer apes and langurs, more macaques, and slow lorises. American Journal of Primatology, 79(22517), 1-13. https://doi.org/10.1002/ajp.22517.

Norouzzadeh, M. S., Nguyen, A., Kosmala, M., Swanson, A., Palmer, M. S., Packer, C., \& Clune, J. (2018). Automatically identifying, counting, and describing wild animals in camera-trap images with deep learning. Proceedings of the National Academy of Sciences of the USA, 115(25), E5716-E5725. https://doi.org/10.1073/pnas.1719367115.

Nowak, M. M., Dziób, K., \& Bogawski, P. (2019). Unmanned aerial vehicles (UAVs) in environmental biology: A review. European Journal of Ecology, 4(2), 56-74. https://doi.org/10.2478/eje-2018-0012.

Nowak, K., Le Roux, A., Richards, S. A., Scheijen, C. P. J., \& Hill, R. A. (2014). Human observers impact habituated samango monkeys' perceived landscape of fear. Behavioral Ecology, 25(5), 1199-1204. https://doi.org/10.1093/beheco/aru110.

Nunn, C. L., \& Gillespie, T. R. (2016). Infectious disease and primate conservation. In S. A. Wich \& A. J. Marshall (Eds.), Primate conservation (pp. 157-168). Oxford University Press.

O’Donoghue, P., \& Rutz, C. (2016). Real-time anti-poaching tags could help prevent imminent species extinctions. Journal of Applied Ecology, 53(1), 5-10. https://doi.org/10.1111/1365-2664.12452.

Oklander, L. I., Caputo, M., Solari, A., \& Corach, D. (2020). Genetic assignment of illegally trafficked neotropical primates and implications for reintroduction programs. Scientific Reports, 10(1), 1-9. https:// doi.org/10.1038/s41598-020-60569-3.

Olivares-Mendez, M. A., Fu, C., Ludivig, P., Bissyandé, T. F., Kannan, S., Zurad, M., Annaiyan, A., Voos, H., \& Campoy, P. (2015). Towards an autonomous vision-based unmanned aerial system against wildlife poachers. Sensors, 31362-31391. https://doi.org/10.3390/s151229861

Olson, E. R., Marsh, R. A., Bovard, B. N., Randrianarimanana, H. L. L., Ravaloharimanitra, M., Ratsimbazafy, J. H., \& King, T. (2012). Arboreal camera trapping for the Critically Endangered greater bamboo lemur Prolemur simus. Oryx, 46(4), 593-597. https://doi.org/10.1017/S0030605312000488.

Ondei, S., Brook, B. W., \& Buettel, J. C. (2019). A flexible tool to prioritize areas for conservation combining landscape units, measures of biodiversity, and threats. Ecosphere, 10(9). https://doi.org/10.1002/ecs2. 2859.

Oude Munnink, B. B., Nieuwenhuijse, D. F., Stein, M., O’Toole, Á., Haverkate, M., Mollers, M., Kamga, S. K., Schapendonk, C., Pronk, M., Lexmond, P., van der Linden, A., Bestebroer, T., Chestakova, I., Overmars, R. J., van Nieuwkoop, S., Molenkamp, R., van der Eijk, A. A., GeurtsvanKessel, C., Vennema, H., et al (2020). Rapid SARS-CoV-2 whole-genome sequencing and analysis for informed public health decision-making in the Netherlands. Nature Medicine. https://doi.org/10.1038/s41591-0200997-y.

Ouso, D. O., Otiende, M. Y., Jeneby, M. M., Oundo, J. W., Bargul, J. L., Miller, S. E., Wambua, L., \& Villinger, J. (2020). Three-gene PCR and high-resolution melting analysis for differentiating vertebrate species mitochondrial DNA for biodiversity research and complementing forensic surveillance. Scientific Reports, 10(1), 1-13. https://doi.org/10.1038/s41598-020-61600-3.

Pafčo, B., Čížková, D., Kreisinger, J., Hasegawa, H., Vallo, P., Shutt, K., Todd, A., Petrželkova, K. J., \& Modrý, D. (2018). Metabarcoding analysis of strongylid nematode diversity in two sympatric primate species. Scientific Reports, 8(1), 1-11. https://doi.org/10.1038/s41598-018-24126-3. 
Parker, J., Helmstetter, A. J., Devey, D., Wilkinson, T., \& Papadopulos, A. S. T. (2017). Field-based species identification of closely-related plants using real-time nanopore sequencing. Scientific Reports, 7(1), 1-8. https://doi.org/10.1038/s41598-017-08461-5.

Patrono, L. V., Pléh, K., Samuni, L., Ulrich, M., Röthemeier, C., Sachse, A., Muschter, S., Nitsche, A., Couacy-Hymann, E., Boesch, C., Wittig, R. M., Calvignac-Spencer, S., \& Leendertz, F. H. (2020). Monkeypox virus emergence in wild chimpanzees reveals distinct clinical outcomes and viral diversity. Nature Microbiology, 5(7), 955-965. https://doi.org/10.1038/s41564-020-0706-0.

Pebsworth, P. A., \& LaFleur, M. (2014). Advancing primate research and conservation through the use of camera traps: Introduction to the special issue. International Journal of Primatology, 35(5), 825-840. https://oi.org/10.1007/s10764-014-9802-4.

Peres, C. A. (1994). Primates responses to phenological in a Amazonian Terra Firme forest. Biotropica, 26(1), 96-112.

Pettorelli, N. (2013). The normalized difference vegetation index. Oxford University Press.

Piel, A. K. (2018). Temporal patterns of chimpanzee loud calls in the Issa Valley, Tanzania: Evidence of nocturnal acoustic behavior in wild chimpanzees. American Journal of Physical Anthropology, 166(3), 530-540. https://doi.org/10.1002/ajpa.23609.

Piel, A. K., Cohen, N., Kamenya, S., Ndimuligo, S. A., Pintea, L., \& Stewart, F. A. (2015). Population status of chimpanzees in the Masito-Ugalla Ecosystem, Tanzania. American Journal of Primatology, 77(10), 1027-1035. https://doi.org/10.1002/ajp.22438.

Pimm, S. L., Alibhai, S., Bergl, R., Dehgan, A., Giri, C., Jewell, Z., Joppa, L., Kays, R., \& Loarie, S. (2015). Emerging technologies to conserve biodiversity. Trends in Ecology and Evolution, 30(11), 685-696. https://doi.org/10.1016/j.tree.2015.08.008.

Pomerantz, A., Peñafiel, N., Arteaga, A., Bustamante, L., Pichardo, F., Coloma, L. A., Barrio-Amorós, C. L., Salazar-Valenzuela, D., \& Prost, S. (2018). Real-time DNA barcoding in a rainforest using nanopore sequencing: Opportunities for rapid biodiversity assessments and local capacity building. GigaScience, 7(4), 1-14. https://doi.org/10.1093/gigascience/giy033.

Quick, J., Grubaugh, N. D., Pullan, S. T., Claro, I. M., Smith, A. D., Gangavarapu, K., Oliveira, G., RoblesSikisaka, R., Rogers, T. F., Beutler, N. A., Burton, D. R., Lewis-Ximenez, L. L., Goes de Jesus, J., Giovanetti, M., Hill, S. C., Black, A., Bedford, T., Carroll, M. W., Marcio Nunes, M., \& Alcantara Jr., L. C. (2017). Multiplex PCR method for MinION and Illumina sequencing of Zika and other virus genomes directly from clinical samples. Nature Protocols, 12(6), 1261-1266. https://doi.org/10.1038/nprot.2017. 066.

Quick, J., Loman, N. J., Duraffour, S., Simpson, J. T., Severi, E., Cowley, L., Akoi Bore, J., Koundouno, R., Dudas, G., Mikhail, A., Ouédraogo, N., Afrough, B., Bah, A., Jonathan Hj Baum, J., Becker-Ziaja, B., Boettcher, J.-P., Cabeza-Cabrerizo, M., Camino-Sanchez, A., Lisa, L., et al (2016). Real-time, portable genome sequencing for Ebola surveillance. Nature, 530(7589), 228-232. https://doi.org/10.1038/ nature16996.

Rodríguez, A., Negro, J. J., Mulero, M., Rodríguez, C., Hernández-Pliego, J., \& Bustamante, J. (2012). The eye in the sky: Combined use of unmanned aerial systems and GPS data loggers for ecological research and conservation of small birds. PLOS ONE, 7(12). https://doi.org/10.1371/journal.pone.0050336.

Rovero, F., \& Zimmerman, F., Eds. (2016). Camera trapping for wildlife research (data in the wild). Pelagic Publishing.

Rovero, F., Zimmermann, F., Berzi, D., \& Meek, P. (2013). "Which camera trap type and how many do I need?" A review of camera features and study designs for a range of wildlife research applications. Hystrix, 24(2), 148-156. https://doi.org/10.4404/hystrix-24.2-6316.

Rowcliffe, J. M., Field, J., Turvey, S. T., \& Carbone, C. (2008). Estimating animal density using camera traps without the need for individual recognition. Journal of Applied Ecology, 45, 1228-1236. https://doi.org/ 10.1111/j.1365-2664.2008.0.

Rowcliffe, J. M., Jansen, P. A., Kays, R., Kranstauber, B., \& Carbone, C. (2016). Wildlife speed cameras: Measuring animal travel speed and day range using camera traps. Remote Sensing in Ecology and Conservation, 2(2), 84-94. https://doi.org/10.1002/rse2.17.

Rowcliffe et al. (2011). Quantifying the sensitivity of camera traps: an adapted distance sampling approach, MEE. https://besjournals.onlinelibrary.wiley.com/doi/10.1111/j.2041-210X.2011.00094.X

Sandbrook, C., Luque-lora, R., Adams, W. M., Sandbrook, C., Luque-lora, R., \& Adams, W. M. (2018). Human bycatch: Conservation surveillance and the social implications of camera traps. Conservation and Society, 16(4), 493-504. https://doi.org/10.4103/cs.cs.

Sarron, J., Malézieux, É., Sané, C. A. B., \& Faye, É. (2018). Mango yield mapping at the orchard scale based on tree structure and land cover assessed by UAV. Remote Sensing, 10(12), 1-21. https://doi.org/10.3390/ rs10121900. 
Schofield, D., Nagrani, A., Zisserman, A., Hayashi, M., Matsuzawa, T., Biro, D., \& Carvalho, S. (2019). Chimpanzee face recognition from videos in the wild using deep learning. Science Advances, 5(9), 1-10. https://doi.org/10.1126/sciadv.aaw0736.

Seah, A., Lim, M. C. W., Mcaloose, D., Prost, S., \& Seimon, T. A. (2020). MinION-based DNA barcoding of preserved and non-invasively collected wildlife samples. Genes, 11(445).

Sebastián-González, E., Camp, R. J., Tanimoto, A. M., de Oliveira, P. M., Lima, B. B., Marques, T. A., \& Hart, P. J. (2018). Density estimation of sound-producing terrestrial animals using single automatic acoustic recorders and distance sampling. Avian Conservation and Ecology, 13(2). https://doi.org/10. 5751/ACE-01224-130207.

Senthilnath, J., Dokania, A., Kandukuri, M. K. N. R., Anand, G., \& Omkar, S. N. (2016). Detection of tomatoes using spectral-spatial methods in remotely sensed RGB images captured by UAV. Biosystems Engineering, 146, 16-32. https://doi.org/10.1016/j.biosystemseng.2015.12.003.

Sharma, K., Fiechter, M., George, T., Young, J., Alexander, J. S., Bijoor, A., Suryawanshi, K., \& MIshra, C. (2020). Conservation and people: Towards an ethical code of conduct for the use of camera traps in wildlife research. Ecological Solutions and Evidence, 1(2), 1-6. https://doi.org/10.1002/2688-8319. 12033.

Sousa-lima, R. S., Norris, T. F., Oswald, J. N., \& Fernandes, D. P. (2013). A review and inventory of fixed autonomous recorders for passive acoustic monitoring of marine mammals. Aquatic Mammals, 39(1), 2353. https://doi.org/10.1578/AM.39.1.2013.

Spaan, D., Burke, C., McAree, O., Aureli, F., Rangel-Rivera, C. E., Hutschenreiter, A., Longmore, S. N., McWhirter, P. R., \& wich, S. A. (2019). Thermal infrared imaging from drones offers a major advance for spider monkey surveys. Drones, 3(2), 34.

Spehar, S. N., \& Rayadin, Y. (2017). Habitat use of Bornean orangutans (Pongo pygmaeus morio) in an industrial forestry plantation in East Kalimantan, Indonesia. International Journal of Primatology, 38(2), 358-384. https://doi.org/10.1007/s10764-017-9959-8.

Spillmann, B., van Noordwijk, M. A., Willems, E. P., Mitra Setia, T., Wipfli, U., \& van Schaik, C. P. (2015). Validation of an acoustic location system to monitor Bornean orangutan (Pongo pygmaeus wurmbii) long calls. American Journal of Primatology, 77(7), 767-776. https://doi.org/10.1002/ajp.22398.

Spillmann, B., van Schaik, C. P., Setia, T. M., \& Sadjadi, S. O. (2017). Who shall I say is calling? Validation of a caller recognition procedure in Bornean flanged male orangutan (Pongo pygmaeus wurmbii) long calls. Bioacoustics, 26(2), 109-120. https://doi.org/10.1080/09524622.2016.1216802.

Srivathsan, A., Ang, A., Vogler, A. P., \& Meier, R. (2016). Fecal metagenomics for the simultaneous assessment of diet, parasites, and population genetics of an understudied primate. Frontiers in Zoology, 13(1), 1-13. https://doi.org/10.1186/s12983-016-0150-4.

Srivathsan, A., Hartop, E., Puniamoorthy, J., Lee, W. T., Kutty, S. N., Kurina, O., \& Meier, R. (2019). Rapid, large-scale species discovery in hyperdiverse taxa using 1D MinION sequencing. BMC Biology, 17, 120.

Stevenson, B. C., Borchers, D. L., Altwegg, R., Swift, R. J., Gillespie, D. M., \& Measey, G. J. (2015). A general framework for animal density estimation from acoustic detections across a fixed microphone array. Methods in Ecology and Evolution, 6(1), 38-48. https://doi.org/10.1111/2041-210X.12291.

Strier, K. B. (1991). Demography and conservation of an Endangered primate, Brachyteles arachnoides. Conservation Biology, 5(2), 214-218.

Sugai, L. S. M., Silva, T. S. F., Ribeiro, J. W., \& Llusia, D. (2019). Terrestrial passive acoustic monitoring: Review and perspectives. BioScience, 69(1), 5-11. https://doi.org/10.1093/biosci/biy147.

Szantoi, Z., Smith, S. E., Strona, G., Koh, L. P., \& Wich, S. A. (2017). Mapping orangutan habitat and agricultural areas using Landsat OLI imagery augmented with unmanned aircraft system aerial photography. International Journal of Remote Sensing, 1-15. https://doi.org/10.1080/01431161.2017.1280638

Tan, T. F., Teoh, S. S., Fow, J. E., \& Yen, K. S. (2016). Embedded human detection system based on thermal and infrared sensors for anti-poaching application. In IEEE Conference on Systems, Process and Control (ICSPC) (pp. 37-42). doi: https://doi.org/10.1109/SPC.2016.7920700

Teelen, S. (2007). Primate abundance along five transect lines at Ngogo, Kibale National Park, Uganda. American Journal of Primatology, 69, 1030-1044. https://doi.org/10.1002/ajp.

van Andel, A. C., Wich, S. A., Boesch, C., Koh, L. P., Robbins, M. M., Kelly, J., \& Kuehl, H. S. (2015). Locating chimpanzee nests and identifying fruiting trees with an unmanned aerial vehicle. American Journal of Primatology, 77(10), 1122-1134. https://doi.org/10.1002/ajp.22446.

Vigilant, L., \& Guschanski, Æ. K. (2009). Using genetics to understand the dynamics of wild primate populations. Primates, 50, 105-120. https://doi.org/10.1007/s10329-008-0124-z.

Voigt, M., Wich, S. A., Ancrenaz, M., Meijaard, E., Abram, N., Banes, G. L., Campbell-Smith, G., d'Arcy, L. J., Delgado, R. A, Erman, A., Gaveau, D., Goossens, B. Heinicke, S., Houghton, M., Husson, S. J., 
Leiman, A., Sanchez, K. L., Makinuddin, N., Meididit, A., et al. (2018). Global demand for natural resources eliminated more than 100,000 Bornean orangutans. Current Biology, 28(5), 761-769.e5. https:// doi.org/10.1016/j.cub.2018.01.053

Wang, Y., Shi, Z. R., Yu, L., Singh, R., Joppa, L., \& Fang, F. (2019). Deep reinforcement learning for green security games with real-time information. In Proceedings of the AAAI Conference on Artificial Intelligence, (pp. 33[01], 1401-1408). https://doi.org/10.1609/aaai.v33i01.33011401

Wasser, S. K., Shedlock, A. M., Comstock, K., Ostrander, E. A., Mutayoba, B., \& Stephen, M. (2004). Assigning African elephant DNA to geographic region of origin: Applications to the ivory trade. Proceedings of the National Academy of Sciences of the USA, 101(41), 14847-14852. https://doi.org/ 10.1073/pnas.0403170101.

Wearn, O. R., \& Glover-Kapfer, P. (2019). Snap happy: Camera traps are an effective sampling tool when compared with alternative methods. Royal Society Open Science, 6(3). https://doi.org/10.1098/rsos. 181748 .

Welbourne, D. J., Clridge, A. W., Paull, D. J., \& Ford, F. (2019). Improving terrestrial squamate surveys with camera trap programming and hardware modifications. Animals, 388(9), 1-18.

Whitworth, A., Braunholtz, L. D., Pillco, R., Macleod, R., \& Beirne, C. (2016). Out on a limb: Arboreal camera traps as an emerging methodology for inventorying elusive rainforest mammals. Tropical Conservation Science, 9(2), 675-698. https://doi.org/10.1177/194008291600900208.

Whytock, R. C., \& Christie, J. (2017). Solo: An open source, customizable and inexpensive audio recorder for bioacoustic research. Methods in Ecology and Evolution, 8(3), 308-312. https://doi.org/10.1111/2041210X.12678.

Wich, S. A., \& Koh, L. P. (2018). Conservation drones. Oxford University Press.

Wich, S. A., Koh, L. P., \& Szantoi, Z. (2018). Classifying land cover on very high resolution drone-acquired orthomosaics: New geospatial approaches to the anthropological sciences. In R. Anemone \& G. C. Conroy (Eds.), New geospatial approaches to the anthropological sciences (pp. 121-136). School of Advanced Research Press.

Wich, S., Dellatore, D., Houghton, M., Ardi, R., \& Koh Pin, L. (2015). A preliminary assessment of using conservation drones for Sumatran orang-utan (Pongo abelii) distribution and density. Journal of Unmanned Vehicle Systems, 4(1), 42-52.

Wich, S., \& Marshall, A. J. (2016). An introduction to primate conservation. In S. A. Wich \& A. Marshall (Eds.), Primate conservation (pp. 1-12). Oxford University Press.

Wich, S., \& Nunn, C. L. (2002). Do male "long-distance calls" function in mate defense? A comparative study of long-distance calls in primates. Behavioral Ecology and Sociobiology, 52(6), 474-484. https://doi.org/ 10.1007/s00265-002-0541-8.

Wijers, M., Loveridge, A., Macdonald, D. W., \& Markham, A. (2019). CARACAL: A versatile passive acoustic monitoring tool for wildlife research and conservation. Bioacoustics, 1-17. https://doi.org/10. 1080/09524622.2019.1685408.

Williamson, E. A., \& Feistner, A. T. C. (2003). Habituating primates: Processes, techniques, variables and ethics. In J. M. Setchell \& D. J. Curis (Eds.), Field and laboratory methods in primatology: A practical guide (pp. 33-50). Cambridge University Press.

Wilson, A. M., Barr, J., \& Zagorski, M. (2017). The feasibility of counting songbirds using unmanned aerial vehicles. The Auk, 134(2), 350-362. https://doi.org/10.1642/AUK-16-216.1.

Zak, A. A., \& Riley, E. P. (2017). Comparing the use of camera traps and farmer reports to study crop feeding behavior of moor macaques (Macaca maura). International Journal of Primatology, 38, 224-242. https:// doi.org/10.1007/s10764-016-9945-6.

Zhang, H., Wang, C., Turvey, S. T., Sun, Z., Tan, Z., Yang, Q., Long, W., Wu, X., \& Yang, D. (2020). Thermal infrared imaging from drones can detect individuals and nocturnal behavior of the world's rarest primate. Global Ecology and Conservation, 23, e01101. https://doi.org/10.1016/j.gecco.2020.e01101.

Zimmermann, E., \& Lerch, C. (1993). The complex acoustic design of an advertisement call in male mouse lemurs (Microcebus murinus, Prosimii, Primates) and sources of its variation. Ethology, 93(3), 211-224. https://doi.org/10.1111/j.1439-0310.1993.tb00990.x. 